\title{
A high-resolution emission inventory of primary pollutants for the Huabei region, China
}

\author{
B. Zhao ${ }^{1, *}$, P. Wang ${ }^{1}$, J. Z. Ma ${ }^{1}$, S. Zhu ${ }^{1, * *}$, A. Pozzer ${ }^{2,3, * * *}$, and W. $\mathbf{L i}^{1}$ \\ ${ }^{1}$ Key Laboratory for Atmospheric Chemistry, Chinese Academy of Meteorological Sciences, Beijing, China \\ ${ }^{2}$ Energy, Environment and Water Research Centre, The Cyprus Institute, Nicosia, Cyprus \\ ${ }^{3}$ Department of Atmospheric Chemistry, Max Planck Institute for Chemistry, Mainz, Germany \\ " now at: Northwest Electric Power Design Institute, Chinese Power Engineering Consulting Group, Xian, China \\ ** now at: Department of Marine, Earth, and Atmospheric Sciences, North Carolina State University, Raleigh, North Carolina, \\ USA \\ **** now at: The Abdus Salam International Centre for Theoretical Physics, Physics of Weather and climate section, Trieste, \\ Italy
}

Correspondence to: J. Z. Ma (mjz@cams.cma.gov.cn)

Received: 8 July 2011 - Published in Atmos. Chem. Phys. Discuss.: 18 July 2011

Revised: 27 November 2011 - Accepted: 29 November 2011 - Published: 10 January 2012

\begin{abstract}
Huabei, located between $32^{\circ} \mathrm{N}$ and $42^{\circ} \mathrm{N}$, is part of eastern China and includes administratively the Beijing and Tianjin Municipalities, Hebei and Shanxi Provinces, and Inner-Mongolia Autonomous Region. Over the past decades, the region has experienced dramatic changes in air quality and climate, and has become a major focus of environmental research in China. Here we present a new inventory of air pollutant emissions in Huabei for the year 2003 developed as part of the project Influence of Pollution on Aerosols and Cloud Microphysics in North China (IPAC-NC).
\end{abstract}

Our estimates are based on data from the statistical yearbooks of the state, provinces and local districts, including major sectors and activities of power generation, industrial energy consumption, industrial processing, civil energy consumption, crop straw burning, oil and solvent evaporation, manure, and motor vehicles. The emission factors are selected from a variety of literature and those from local measurements in China are used whenever available. The estimated total emissions in the Huabei administrative region in 2003 are $4.73 \mathrm{Tg} \mathrm{SO}_{2}, 2.72 \mathrm{Tg} \mathrm{NO}_{\mathrm{x}}$ (in equivalent $\mathrm{NO}_{2}$ ), 1.77 Tg VOC, 24.14 Tg CO, 2.03 Tg NH 3 , 4.57 Tg PM 10 , $2.42 \mathrm{Tg} \mathrm{PM}_{2.5}, 0.21 \mathrm{Tg} \mathrm{EC}$, and 0.46 Tg OC.

For model convenience, we consider a larger Huabei region with Shandong, Henan and Liaoning Provinces included in our inventory. The estimated total emissions in the larger Huabei region in 2003 are: $9.55 \mathrm{Tg} \mathrm{\textrm {SO } _ { 2 }}$, 5.27 Tg $\mathrm{NO}_{\mathrm{x}}$ (in equivalent $\mathrm{NO}_{2}$ ), $3.82 \mathrm{Tg} \mathrm{VOC}, 46.59 \mathrm{Tg}$
$\mathrm{CO}, 5.36 \mathrm{Tg} \mathrm{NH} \mathrm{NH}_{3}, 10.74 \mathrm{Tg} \mathrm{PM}_{10}, 5.62 \mathrm{Tg} \mathrm{PM}_{2.5}, 0.41 \mathrm{Tg}$ $\mathrm{EC}$, and $0.99 \mathrm{Tg} \mathrm{OC}$. The estimated emission rates are projected into grid cells at a horizontal resolution of $0.1^{\circ}$ latitude by $0.1^{\circ}$ longitude. Our gridded emission inventory consists of area sources, which are classified into industrial, civil, traffic, and straw burning sectors, and large industrial point sources, which include 345 sets of power plants, iron and steel plants, cement plants, and chemical plants.

The estimated regional $\mathrm{NO}_{2}$ emissions are about 2-3\% (administrative Huabei region) or $5 \%$ (larger Huabei region) of the global anthropogenic $\mathrm{NO}_{2}$ emissions. We compare our inventory (IPAC-NC) with the global emission inventory EDGAR-CIRCE and the Asian emission inventory INTEXB. Except for a factor of 3 lower EC emission rate in comparison with INTEX-B, the biases of the total emissions of most primary air pollutants in Huabei estimated in our inventory, with respect to EDGAR-CIRCE and INTEX-B, generally range from $-30 \%$ to $+40 \%$. Large differences up to a factor of 2-3 for local emissions in some areas (e.g. Beijing and Tianjin) are found. It is recommended that the inventories based on the activity rates and emission factors for each specific year should be applied in future modeling work related to the changes in air quality and atmospheric chemistry over this region. 


\section{Introduction}

North China or Huabei in Chinese (hereafter we use the latter) is a geographical region located in the northern part of eastern China, including several provinces and large municipalities, e.g. Beijing and Tianjin, both with populations greater than 10 million. Being influenced by both anthropogenic activities and natural desert, Huabei has become one of the most severely polluted regions in China as indicated by numerous studies including both ground measurements (e.g. Yan et al., 2008; Li et al., 2007; Lin et al., 2008, 2009; Meng et al., 2009; Pan et al., 2009; Sun et al., 2010; Tang et al., 2007) and satellite data analyses (e.g. Xu and Lin, 2010; Chen et al., 2009; Peng et al., 2007; Li et al., 2003a; Ma et al., 2006b; Richter et al., 2005; Shi et al., 2008; Tie et al., 2006; Zhang et al., 2007; Zhao et al., 2006). The project Influence of Pollution on Aerosols and Cloud Microphysics in North China (IPAC-NC) was implemented to assess the causes of such severe pollution and its potential impact on regional climate (Ma et al., 2010, 2011). As part of the IPAC-NC project, we have developed a high-resolution emission inventory of primary pollutants for the Huabei region of China. Our objective is to provide a reliable emission database that can be used to drive the regional, meteorologychemistry coupled model with fine-grid cells (e.g. at a horizontal resolution of $0.1^{\circ}$ latitude by $0.1^{\circ}$ longitude), to better understand chemical and physical processes involved in dramatic changes in air quality and climate over this part of China in the 2000s and find their linkages with energy consumption and technology innovation.

The emission inventory and its accuracy are important for the ability of modeling studies to characterize the historical, present and future states of the atmospheric environment (Frey et al., 1999; Russell and Dennis, 2000; Ma and van Aardenne, 2004). Global and Asian emission inventories naturally include the estimates for a specific region, e.g. Huabei, China. Global emission inventories, e.g. EDGAR (the Emission Database for Global Atmospheric Research) v32 (Olivier et al., 2002); EDGAR v3.2 Fast Track 2000 (Olivier et al., 2005; data available at http://www.mnp.nl/edgar/model/v32ft2000edgar), IPCCAR4 (Dentener et al., 2005; data available at ftp://ftp-ccu.jrc. $\mathrm{it} / \mathrm{pub} / \mathrm{dentener/IPCC-AR4/2000),} \mathrm{and} \mathrm{RETRO} \mathrm{(Pulles} \mathrm{et} \mathrm{al.,}$ 2007; data available at http://retro.enes.org), generally have too low grid resolution (e.g. $1^{\circ}$ latitude by $1^{\circ}$ longitude) for urban/regional model simulations. Moreover, there are very large differences (often a factor of two) between the emissions for individual cities, even when the total global emissions are very similar (Butler et al., 2008). The use of an ensemble of inventories, increased attention to the geographical distribution of emissions and better integration of local inventories into global emission inventories has been recommended (Butler et al., 2008).

Several Asian emission inventories were developed for the support of different projects and associated field cam- paigns that focused on the impacts of Asian pollution outflow on West-Pacific and North America, e.g. TRACE$\mathrm{P}$ (Transport and Chemical Evolution over the Pacific) campaign in 2001 (Jacob et al., 2003) and INTEX-B (Intercontinental Chemical Transport Experiment-B) campaign in 2006 (Singh et al., 2009). Almost all of these inventories, e.g. TRACE-P (Streets et al., 20003; data available at http://www.cgrer.uiowa.edu/EMISSION DATA/index_16.htm), REAS (Ohara et al., 2007), and INTEX-B (Zhang et al., 2009; data available at http://mic. greenresource.cn/intex-b2006 or http://www.cgrer.uiowa. edu/EMISSION_DATA_new/index_16.htm) were initially estimated by province for China and by country for the rest of Asia. They are generally distributed at the same $\left(1^{\circ}\right.$ latitude by $1^{\circ}$ longitude for TRACE-P) or slightly finer $\left(0.5^{\circ}\right.$ latitude by $0.5^{\circ}$ longitude for REAS and INTEX-B) grid resolution, although it was declared that the data with much finer resolution $\left(0.3^{\circ}\right.$ latitude by $0.3^{\circ}$ longitude for TRACE-P and INTEX-B) might be accessed. While these emission inventories have widely been used and evaluated in model simulations (e.g. Carmichael et al., 2003), the comparisons of model results with measurements for the polluted regions inside China (e.g. Huabei) are relatively few. It was shown that the uncertainty in the emission estimates may result in 30$50 \%$ differences in surface ozone concentrations in polluted areas of China (Ma and van Aardenne, 2004).

Regional pollution related to photochemical smog and haze-fog has been recognized as one of the severe environmental problems in China (Zhang et al., 2008; Ma et al., 2010). The most serious pollution regions are typically the Huabei region with the Beijing and Tianjin megacities included, the Yangtze River Delta region with the Shanghai megacity included, and the Pear River Delta region (PRD) with the Guangzhou and Hong Kong megacities included. Such air pollution not only has adverse effects on human health and the ecosystems, but also has large impacts on weather and climate in urban and regional scales. Accurate and highly-resolved emission inventories are essential for understanding pollution formation and transport, planning abatement and control measures, and operating chemical weather forecasting in these regions. Wang et al. (2005b) developed a source-specific, high-resolution emission inventory for the Shandong region of eastern China for the year 2000 and implemented it to a regional chemical transport model of $12 \mathrm{~km} \times 12 \mathrm{~km}$ horizontal resolution. Cao et al. (2006) presented a high-resolution emission inventory of elemental carbon (EC) and organic carbon (OC) aerosols in China for the year 2000 with $0.2^{\circ}$ latitude $\times 0.2^{\circ}$ longitude resolution. Recently, Zheng et al. (2009b) developed a highly resolved temporal and spatial emission inventory for the PRD for the year 2006 and allocated it onto grid cells with a resolution of $3 \mathrm{~km} \times 3 \mathrm{~km}$. They further established a speciated VOC emission inventory on the basis of this emission inventory and local VOC source profiles and evaluated spatial patterns of ozone formation potential in the PRD (Zheng et al., 
2009a). Although there have been many emission estimates for Chinese regions, these studies were generally limited, either focusing on one specific city (e.g. Liu and Shao, 2007; Pang and Mu, 2007; Bo et al., 2008; Zhao and Ma, 2008) or one specific sector (Dai et al., 2010; Cai and Xie, 2007, 2009; Cao et al., 2008; Liu et al., 2011; Zhao et al., 2008) or on a special kind of pollutant (Bo et al., 2008; Lu et al., 2010; Lei et al., 2011). To our knowledge, a highly-resolved, gridded emission inventory covering different years for the entire region of China has not been available. Although almost all the developers could give the uncertainties of their own emission inventories (e.g. Streets et al., 2003; Zhang et al., 2009; Zhao et al., 2011), uncertainties in current estimates of Chinese emissions were not evaluated systematically as for North America and Europe (Frey et al., 1999; Zheng, 2002; Bobley et al., 2005).

In this paper, we present a high-resolution emission inventory of the major air pollutants developed for the Huabei region of China for the year 2003. Our inventory includes sulfur dioxide $\left(\mathrm{SO}_{2}\right)$, nitrogen oxides $\left(\mathrm{NO}_{\mathrm{x}} \equiv \mathrm{NO}+\mathrm{NO}_{2}\right)$, VOC (abbreviated from NMVOC, Non-Methane Volatile Organic Compounds), carbon monoxide (CO), ammonia $\left(\mathrm{NH}_{3}\right)$, particulate matter of diameter smaller than or equal to $10 \mu \mathrm{m}$ $\left(\mathrm{PM}_{10}\right)$, particulate matter of diameter smaller than or equal to $2.5 \mu \mathrm{m}\left(\mathrm{PM}_{2.5}\right), \mathrm{EC}$, and OC. In Sect. 2 we describe the methodology and data sources used in this study. In Sect. 3 we present our emission inventory by sectors, provinces and fine-grid cells (with a horizontal resolution of $0.1^{\circ}$ latitude by $0.1^{\circ}$ longitude). In Sect. 4 we estimate the uncertainties of our estimates in comparison with other emission inventories. A summary of our inventory is given in Sect. 5.

\section{Methodology}

\subsection{General description}

Huabei is a part of eastern China, located approximately between $32^{\circ} \mathrm{N}$ and $42^{\circ} \mathrm{N}$ latitude in a geographical sense. Administratively it is a region including Beijing and Tianjin Municipalities, Hebei and Shanxi Provinces, and InnerMongolia Autonomous Region. For model convenience, the statistical data for Shandong, Henan and Liaoning Provinces are also taken into account in our inventory although these provinces do not belong to Huabei currently in an administrative sense (Fig. 1). Table 1 gives a summary of social and economic index in Huabei, and Table 2 presents the energy use by fuel type in the region. Beijing, Tianjin, Hebei, Shandong, and Liaoning together compose the main industrial base of China, Shanxi is an important energy base, Henan is a large agricultural province, and Inner-Mongolia is one of the dust storm sources in northern China.

We use a bottom-up approach to develop the emission inventory for the Huabei region, considering only anthropogenic emissions on an annual basis. The annual anthro-

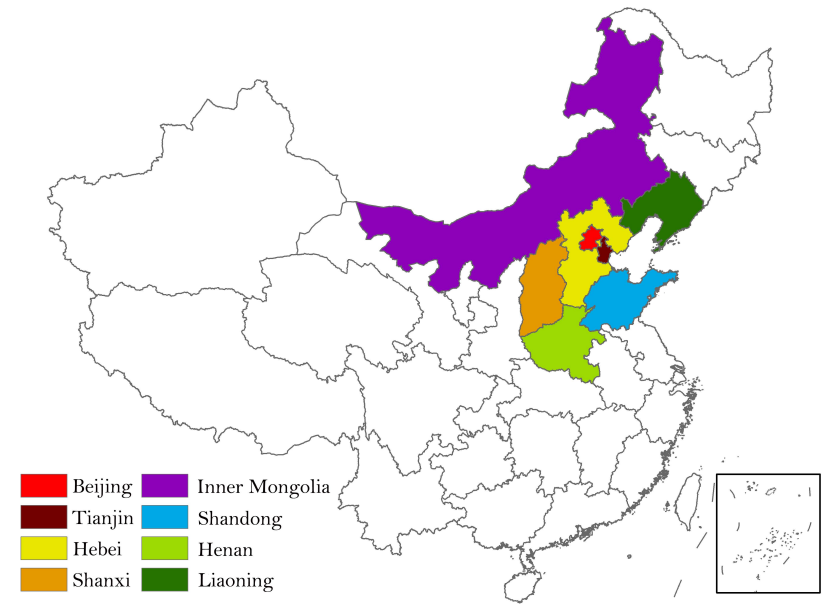

Fig. 1. The larger Huabei region (highlighted in colour) and its location in China.

pogenic emission rate of the $i$-th chemical species in the $j$-th area, $Q_{i, j}$, is calculated as

$Q_{i, j}=\sum_{k=1}^{n} A_{j, k} F_{i, j, k}$

where $A_{j, k}$ is the annual rate of the k-th activity or fuel use in the $j$-th area, $F_{i, j, k}$ is the emission factor of the $k$-th activity or fuel use for the $i$-th species in the $j$-th area, and $n$ is the total number of activities or fuel types in the area. The chemical species or pollutants we consider are $\mathrm{SO}_{2}, \mathrm{NO}_{\mathrm{x}}$, VOC, $\mathrm{CO}, \mathrm{NH}_{3}, \mathrm{PM}_{10}, \mathrm{PM}_{2.5}, \mathrm{EC}$, and OC. Molar or total masses of each species or pollutant are calculated. As in previous studies (e.g. van Aardenne et al., 1999; Zhang et al., 2009), we use the equivalent $\mathrm{NO}_{2}$ masses to represent the amount of emitted $\mathrm{NO}_{\mathrm{x}}$, although $\mathrm{NO}_{\mathrm{x}}$ from fossil fuel burning is generally released in the form of $\mathrm{NO}(>90 \%)$. In this study, we present the emissions in the Huabei region for the year 2003, which was the latest year for which Chinese statistical data could be obtained when the IPAC-NC project started. Although some new emission inventories have been available for the years after 2003, e.g. INTEX-B for 2006 (Zhang et al., 2009), we still believe that our emission inventory will be very useful for model work on historical trend and field experimental data analyses.

The emission sources in our inventory are divided into four major categories including industrial, civil, traffic, and straw burning. Each major category has various sub-sectors and associated activity types, as shown in Table 3. Compared to existing global or Asian emission inventories, an advantage of our emission inventory is that we collected the original data from the statistical yearbooks of local districts (which have an administrative level between province and county in China), instead of only provinces. The major sectors and activities included in our inventory are power generation, industrial energy consumption, industrial processing, 
Table 1. Social and economic index of the larger Huabei region in 2003.

\begin{tabular}{llrrrrrr}
\hline No. & $\begin{array}{l}\text { Administrative } \\
\text { region }\end{array}$ & $\begin{array}{r}\text { Area } \\
\left(10^{4} \mathrm{~km}^{2}\right)\end{array}$ & $\begin{array}{r}\text { Population } \\
\left(10^{6}\right)\end{array}$ & $\begin{array}{r}\text { GDP } \\
\left(10^{8} ¥\right)\end{array}$ & $\begin{array}{r}\text { Ind-P } \\
\left(10^{8} ¥\right)\end{array}$ & $\begin{array}{r}\text { Agr-P } \\
\left(10^{8} ¥\right)\end{array}$ & $\begin{array}{r}\text { Energy Use } \\
\left(10^{6} \text { ton SC }\right)\end{array}$ \\
\hline 1 & Beijing & 1.68 & 14.56 & 3663.1 & 4259.3 & 148.3 & 47.08 \\
2 & Tianjin & 1.13 & 10.11 & 2447.7 & 4049.6 & 181.1 & 32.15 \\
3 & Hebei & 18.77 & 67.69 & 7122.0 & 5708.8 & 958.3 & 134.77 \\
4 & Shanxi & 15.63 & 33.14 & 2456.6 & 2414.4 & 249.5 & 103.87 \\
5 & Inner-Monglia & 118.3 & 23.80 & 2150.4 & 2055.0 & 336.0 & 52.18 \\
6 & Shandong & 15.38 & 91.25 & 12435.9 & 19891.5 & 1599.3 & 130.34 \\
7 & Henan & 16.70 & 96.67 & 7048.6 & 3034.1 & 673.5 & 95.62 \\
8 & Liaoning & 14.59 & 42.10 & 6002.5 & 2884.1 & 497.3 & 114.49 \\
\hline
\end{tabular}

GDP: Gross domestic product; Ind-P: Industrial product; Agr-P: Agricultural product; ¥: Chinese currency, Yuan; SC: standard coal, and 1 kg SC is equivalent to any fuel that produces 29.27 MJ of heat energy. Sources are from China Statistical Bureau .(2004a; 2004e).

Table 2. Annual energy use in the larger Huabei region in 2003.

\begin{tabular}{llrrrrrr}
\hline No. & $\begin{array}{l}\text { Administrative } \\
\text { region }\end{array}$ & $\begin{array}{r}\text { Coal } \\
\left(10^{4} \text { ton SC }\right)\end{array}$ & $\begin{array}{r}\text { Coke } \\
\left(10^{4} \text { ton SC }\right)\end{array}$ & $\begin{array}{r}\text { Oil } \\
\left(10^{4} \text { ton SC }\right)\end{array}$ & $\begin{array}{r}\text { Natural } \\
\text { Gas }\left(10^{8} \mathrm{~m}^{3}\right)\end{array}$ & $\begin{array}{r}\text { Coal Gas } \\
\left(10^{8} \mathrm{~m}^{3}\right)\end{array}$ & $\begin{array}{r}\text { LPG } \\
\left(10^{4} \text { ton SC }\right)\end{array}$ \\
\hline 1 & Beijing & 2007.4 & 462.0 & 485.7 & 22.6 & 139.5 & 32.8 \\
2 & Tianjin & 1642.3 & 140.6 & 271.2 & 5.0 & 2.3 & 79.7 \\
3 & Hebei & 9873.0 & 300.0 & 145.7 & 2.2 & 189.3 & 22.4 \\
4 & Shanxi & 13275.0 & 469.9 & 359.7 & 423.7 & 7.62 & 0.73 \\
5 & Inner-Monglia & 5953.0 & 472.0 & 360.0 & 9.7 & 106.7 & 189.2 \\
6 & Shandong & 12800.0 & 475.9 & 538.6 & 55.3 & 126.8 & 73.0 \\
7 & Henan & 7691.9 & 128.0 & 233.9 & 0.01 & 13.8 & 4.6 \\
8 & Liaoning & 7041.6 & 58.7 & 127.6 & 24.0 & 5.0 & 276.0 \\
\hline
\end{tabular}

Oil includes gasoline, diesel oil, fuel oil, crude oil, and others excluding automobile usage. LPG: liquefied petroleum gas; SC: standard coal. Sources are from China Statistical Bureau (2004a).

civil energy consumption, crop straw burning, oil and solvent evaporation, manure, and motor vehicles. Another advantage of our emission inventory is that we have performed an intensive literature research on the emission factors and tried to use the ones derived by local measurements in China whenever possible.

We investigated the annual product of large power plants, iron and steel plants, cement plants, fertilizer plants, coke plants, petrochemical plants, grains and oil plants, sulfuric acid plants, and paint plants in Huabei (345 in total), defined their geographical positions exactly by latitude and longitude, and estimated the emissions of $\mathrm{SO}_{2}, \mathrm{NO}_{\mathrm{x}}, \mathrm{VOC}$, $\mathrm{CO}, \mathrm{NH}_{3}, \mathrm{PM}_{10}, \mathrm{PM}_{2.5}, \mathrm{EC}$, and $\mathrm{OC}$ from these plants as point sources. The total emissions in the districts or counties were deduced by the emissions from these point sources correspondingly, and the rest were mapped into the gridded cells using geographical information system (GIS) to get the emissions of area sources. A gridded emission inventory of Huabei with a $0.1^{\circ}$ latitude $\times 0.1^{\circ}$ longitude resolution was derived based on these point and area source emission rates.

\subsection{Activity rates}

We performed a detailed analysis of the statistical data of local districts in Huabei (e.g. China Statistic Bureau, 2004a; China Statistic Bureau, 2004b; China Electric Power Yearbook Editorial Board, 2004; China Steel Industrial Association, 2004; China Traffic Yearbook Editorial Board, 2004). The pollution sources are separated into various sectors including power generation, industrial energy consumption, industrial processing, civil energy consumption, crop straw burning, central heating, oil and solvent evaporation, major ammonia sources, major particle sources, cooking, and motor vehicles. The industrial energy sector is subdivided into different fuel types including coal, coke, gasoline, diesel oil, fuel oil, crude oil, liquefied petroleum gas (LPG), coal gas, and natural gas. The industrial processing sector refers to emissions during the production of fertilizer, sulfuric acid, ammonia, cement, iron, steel, coke, paints, vegetable oil and crude oil excluding fuel burning. The emissions from these two industrial sectors (energy consumption and processing) are distributed according to the industrial production quantity of the counties. 
Table 3. Emission source categorization in the larger Huabei region.

\begin{tabular}{|c|c|c|}
\hline Major Category & Sub-category & Fuel or activity types \\
\hline \multicolumn{3}{|l|}{ Industry } \\
\hline & Power generation & Coal \\
\hline & Industrial fuel use & $\begin{array}{l}\text { Coal, coke, gasoline, diesel oil, fuel oil, crude oil, other } \\
\text { oil natural gas, LPG, coal gas }\end{array}$ \\
\hline & Industrial processing & $\begin{array}{l}\text { Fertilizer, sulfuric acid, ammonia, cement, sintering, } \\
\text { iron, steel, roller steel, coke, crude oil, paints, vegetable } \\
\text { oil }\end{array}$ \\
\hline \multicolumn{3}{|l|}{ Civil } \\
\hline & Civil fuel use & Coal, LPG, coal gas, natural gas, coal gas, coal gas BS \\
\hline & Other civil activities & $\begin{array}{l}\text { Central heating, solvent \& oil evaporation, cooking, } \\
\text { manure (man, animal and soil fertilization), traffic dust }\end{array}$ \\
\hline \multicolumn{3}{|l|}{ Traffic } \\
\hline & Passenger vehicles & Large, middle, small, mini (gasoline and diesel) \\
\hline & Goods vehicles & Large, middle, small, mini (gasoline and diesel) \\
\hline & Other vehicles & Motorcycles, tractors (gasoline and diesel) \\
\hline \multicolumn{3}{|l|}{ Straw burning } \\
\hline & Straw burning & Wheat, corn, rice, cotton, oil, others \\
\hline
\end{tabular}

The civil energy sector is also subdivided into different fuel types including civil coal, civil LPG, civil natural gas, and civil coal gas for benefit stove (BS). The emissions from the civil energy sector, central heating, oil and paint evaporation, and motor vehicles are distributed according to the population of the counties. The emissions from the straw burning sector are distributed according to the agricultural production of the counties. Table 4 presents the annual crop straw masses burned for each province in Huabei in the year 2003.

The major ammonia sources include animal, man, and fertilizer applications, which are estimated based on animal husbandry production, population, and sowing areas, respectively. While the emissions due to traffic blowing dust are estimated, particle sources from building construction and bare land are not taken into account in this study. Motor vehicles are subdivided into passenger vehicles (large, middle, small, and mini), goods vehicles (heavy, middle, light, and mini), motorcycles, and tractors. The numbers of gasoline and diesel vehicles in each type are taken into account. The emissions of motor vehicles are estimated as the product of numbers of vehicles in a county or district, annual distance traveled in $\mathrm{km}$, and emission factor in $\mathrm{g} \mathrm{km}^{-1}$ of pollutant emitted. Table 5 provides the motor vehicle numbers by province in Huabei in the year 2003.

\subsection{Emission factors}

The emission factors are very important for the accuracy of an emission inventory. The emission inventories developed previously for China were mostly based on the emission factors measured abroad, which may not be completely suitable for the situation in China. Since some measurements of emission factors, especially in the Huabei region of China, have been performed (e.g. Jiang and Tang, 2002), we try to use these local emission factors in our calculations as much as possible. Tables 6-11 show the emission factors of various fuel composition and activities adopted in our inventory. Below we give a general description of the selection or estimation of the specific emission factors of our inventory.

\subsubsection{Coal burning}

Due to high coal burning efficiency ( $>90 \%$ ) for boilers in the power plants, the $\mathrm{CO}$ and $\mathrm{EC}$ emission factors for power generation are much lower than those for other coal-burning activities (Table 6). Although sulfur burning efficiency is high under such boiler conditions, the $\mathrm{SO}_{2}$ emission factor for power generation is also lower since low-sulfur-content coal and desulfurization technology have been widely used in the power plants. The coal-burning efficiency in residential use is much lower than that $(\sim 80 \%)$ for industrial boilers. As a result, the $\mathrm{SO}_{2}$ and $\mathrm{NO}_{\mathrm{x}}$ emission factors for coal burning 
Table 4. Annual straw masses burned in the larger Huabei region in 2003.

\begin{tabular}{llrrrrrr}
\hline No. & $\begin{array}{l}\text { Administrative } \\
\text { region }\end{array}$ & $\begin{array}{r}\text { Wheat Straw } \\
\left(10^{4} \text { ton }\right)\end{array}$ & $\begin{array}{r}\text { Corn Straw } \\
\left(10^{4} \text { ton }\right)\end{array}$ & $\begin{array}{r}\text { Rice Straw } \\
\left(10^{4} \text { ton }\right)\end{array}$ & $\begin{array}{r}\text { Cotton Straw } \\
\left(10^{4} \text { ton }\right)\end{array}$ & $\begin{array}{r}\text { Oil Straw } \\
\left(10^{4} \text { ton }\right)\end{array}$ & $\begin{array}{r}\text { Other Straw } \\
\left(10^{4} \text { ton }\right)\end{array}$ \\
\hline 1 & Beijing & 25.1 & 64.4 & 0.6 & 1.0 & 6.6 & 4.2 \\
2 & Tianjin & 49.1 & 129.6 & 0 & 28.4 & 6.2 & 18.6 \\
3 & Hebei & 1391.7 & 2147.2 & 25.6 & 156.6 & 326.2 & 151.6 \\
4 & Shanxi & 349.7 & 953.9 & 23.9 & 27.5 & 72.7 & 143.2 \\
5 & Inner-Monglia & 127.8 & 1777.4 & 44.8 & 0.78 & 217.8 & 131.1 \\
6 & Shandong & 2137.8 & 2822.0 & 57.9 & 263.0 & 723.6 & 268.8 \\
7 & Henan & 3131.6 & 1532.6 & 183.5 & 113.0 & 619.8 & 187.3 \\
8 & Liaoning & 8.3 & 1861.0 & 208.7 & 1.0 & 122.8 & 204.0 \\
\hline
\end{tabular}

Sources are from the China Ministry of Agriculture/US Department of Energy Project Panel (1998) and China Statistical Bureau (2004a).

Table 5. Numbers of motor vehicles in the larger Huabei region in 2003.

\begin{tabular}{|c|c|c|c|c|c|c|c|c|c|c|c|}
\hline \multirow[t]{2}{*}{ No. } & \multirow[t]{2}{*}{ Administrative region } & \multicolumn{5}{|c|}{ Passenger Vehicles $\left(10^{4}\right)$} & \multicolumn{3}{|c|}{ Goods Vehicles $\left(10^{4}\right)$} & \multirow[t]{2}{*}{ Motorcycles $\left(10^{4}\right)$} & \multirow[t]{2}{*}{ Tractors $\left(10^{4}\right)$} \\
\hline & & Large & Middle & Small & Mini & Heavy & Middle & Light & Mini & & \\
\hline 1 & Beijing & 3.24 & 10.59 & 106.73 & 20.84 & 3.04 & 6.89 & 16.39 & 0.53 & 27.68 & 3.11 \\
\hline 2 & Tianjin & 1.38 & 2.97 & 22.78 & 11.11 & 3.45 & 3.88 & 11.57 & 1.68 & 36.39 & 5.34 \\
\hline 3 & Hebei & 2.85 & 2.15 & 59.02 & 23.37 & 29.90 & 17.30 & 107.77 & 3.99 & 425.81 & 142.07 \\
\hline 4 & Shanxi & 1.37 & 2.28 & 26.30 & 10.72 & 12.55 & 10.73 & 76.58 & 4.08 & 73.29 & 21.54 \\
\hline 5 & Inner-Monglia & 1.27 & 1.84 & 19.67 & 5.87 & 10.91 & 9.18 & 50.20 & 0.97 & 87.41 & 54.11 \\
\hline 6 & Shandong & 3.86 & 7.55 & 64.85 & 27.94 & 13.83 & 21.22 & 423.44 & 7.24 & 749.08 & 183.40 \\
\hline 7 & Henan & 4.22 & 6.29 & 41.38 & 17.40 & 19.91 & 15.27 & 148.13 & 6.78 & 290.01 & 198.54 \\
\hline 8 & Liaoning & 5.20 & 4.91 & 48.08 & 6.39 & 13.65 & 12.37 & 45.86 & 1.02 & 99.13 & 10.38 \\
\hline
\end{tabular}

Buses are included in the middle passenger vehicles, and cars and taxi in the mini passenger vehicles. Trailers and farm transporters are included in the heavy and light goods vehicles, respectively. Sources are from the China Statistical Bureau (2004a).

are lower, and the $\mathrm{CO}$ and $\mathrm{EC}$ emission factors are much higher in the civil sector than those in the industrial sector. The sulfur content of the coal used in the larger Beijing, Tianjin, and Tangshan areas (called Jing-Jin-Tang in Chinese) is lower ( $\sim 0.6 \%$ in average) than in the rest of Huabei $(\sim 0.92 \%)$ (Bai, 1996; Jiang and Tang, 2002). Moreover, more advanced production technology has been adopted in Jing-Jin-Tang than in the other areas. Therefore, lower $\mathrm{SO}_{2}$ emission factors for coal burning are used for Jing-Jin-Tang and its nearby areas than for the rest of Huabei in our inventory.

\subsubsection{Industrial processes}

In addition to fuel combustion, some pollutants are emitted during industrial processes (Table 7). The emission factors of $\mathrm{SO}_{2}, \mathrm{PM}_{10}$, and $\mathrm{PM}_{2.5}$ for the steel processing are taken from local experimental results (Jiang and Tang, 2002). The $\mathrm{CO}$ emission factor for steel processing is determined using a $\mathrm{CO}$ emission factor reported by previous work (Wang et al., 2005a), weighted by the fraction of steelmaking processes (e.g. converter and electric furnace). The methods of coke making, including uncontrollable heap coking and control- lable mechanical coking, have large effects on the amount of $\mathrm{EC}$ and $\mathrm{OC}$ emitted during the coke processing. The EC and OC emission factors for the coking process are estimated according to the work of Bond et al. (2004) with a mechanical coking method assumed.

\subsubsection{Straw burning}

Crop straw burning is an important way of obtaining energy for cooking and heating in the countryside of China. Since the residential stoves used for burning straw are small and the water content of straw burned is high, the burning temperatures and burning efficiency are generally low and the emission factors of major pollutants are large. With increasing crop yields and the possibility of using other energy sources, open-air straw burning in the field has occurred more frequently in the developed areas of Huabei, e.g. Beijing and Tianjin. The $\mathrm{NO}_{\mathrm{x}}$ and $\mathrm{SO}_{2}$ emission factors for crop straw burning are taken from the work of Tian et al. (2002), with wheat straw, corn straw, rice straw, and oil straw as herbal straw and cotton straw as core wood. The CO and VOC emission factors are taken from the work of Fine et al. (2001), which are typically applicable to the traditional 
Table 6. Emission factors for power generation, industrial and civil fuel combustion.

\begin{tabular}{|c|c|c|c|c|c|c|c|c|c|c|}
\hline Fuel & $\mathrm{SO}_{2}$ & $\mathrm{NO}_{\mathrm{x}}$ & VOC & $\mathrm{CO}$ & $\mathrm{NH}_{3}$ & $\mathrm{PM}_{10}$ & $\mathrm{PM}_{2.5}$ & $\mathrm{EC}$ & $\mathrm{OC}$ & Units \\
\hline \multicolumn{11}{|c|}{ Power Generation } \\
\hline Coal & $8.46-16.56^{*}$ & 6.58 & $0.032^{1}$ & $2.48^{2}$ & 0 & 0.870 & 0.620 & $0.010^{3}$ & $0.250^{3}$ & $\mathrm{~g} \mathrm{~kg}^{-1}$ \\
\hline \multicolumn{11}{|c|}{ Industrial Fuel } \\
\hline Coal & $10.0-15.38^{*}$ & 4.00 & $0.032^{1}$ & $15.0^{2}$ & 0 & 1.61 & 0.74 & $0.150^{4}$ & $0.500^{4}$ & $\mathrm{~g} \mathrm{~kg}^{-1}$ \\
\hline Coke & $19.0^{1}$ & $4.80^{1}$ & $0.032^{1}$ & $6.60^{5}$ & 0 & $0.288^{5}$ & $0.144^{5}$ & $0.030^{4}$ & $0.006^{4}$ & $\mathrm{~g} \mathrm{~kg}^{-1}$ \\
\hline Gasoline & 1.60 & $16.7^{6}$ & $0.087^{1}$ & $0.473^{1}$ & 0 & $0.250^{5}$ & $0.125^{5}$ & $0.026^{4}$ & $0.004^{4}$ & $\mathrm{~g} \mathrm{~kg}^{-1}$ \\
\hline Diesel oil & 2.24 & $9.62^{6}$ & $0.093^{1}$ & 0.780 & 0 & 0.310 & 0.310 & $0.026^{4}$ & $0.004^{4}$ & $\mathrm{~g} \mathrm{~kg}^{-1}$ \\
\hline Fuel oil & 2.24 & $5.84^{6}$ & $0.093^{1}$ & 0.780 & 0 & 0.310 & 0.310 & $0.040^{4}$ & $0.015^{4}$ & $\mathrm{~g} \mathrm{~kg}^{-1}$ \\
\hline Crude oil & 2.75 & $5.09^{6}$ & $0.093^{1}$ & 0.860 & 0 & 1.60 & 0.060 & $0.040^{4}$ & $0.015^{4}$ & $\mathrm{~g} \mathrm{~kg}^{-1}$ \\
\hline Other oil & 2.24 & $7.46^{6}$ & $0.093^{1}$ & 0.780 & 0 & 0.310 & 0.310 & $0.040^{4}$ & $0.015^{4}$ & $\mathrm{~g} \mathrm{~kg}^{-1}$ \\
\hline Natural gas & 0.180 & 1.76 & $0.285^{1}$ & 0.350 & 0 & 0.240 & 0.170 & 0 & 0 & $\mathrm{~g} \mathrm{~m}^{-3}$ \\
\hline LPG & 0.180 & 2.10 & $0.185^{5}$ & 0.420 & 0 & 0.220 & 0.150 & 0 & 0 & $\mathrm{~g} \mathrm{~kg}^{-1}$ \\
\hline Coal Gas & 0.080 & 0.800 & $0.243^{1}$ & 0.160 & 0 & 0.240 & 0.170 & 0 & 0 & $\mathrm{~g} \mathrm{~m}^{-3}$ \\
\hline \multicolumn{11}{|l|}{ Civil Fuel } \\
\hline Coal & 8.62 & $1.88^{6}$ & $0.032^{1}$ & $52.3^{2}$ & 0 & 1.62 & 0.770 & $0.280^{7}$ & $0.470^{8}$ & $\mathrm{~g} \mathrm{~kg}^{-1}$ \\
\hline LPG & 0.180 & 2.10 & $0.088^{5}$ & 0.420 & 0 & 0.220 & 0.150 & 0 & 0 & $\mathrm{~g} \mathrm{~kg}^{-1}$ \\
\hline Natural gas & 0.180 & 1.76 & $0.088^{5}$ & 0.350 & 0 & 0.240 & 0.100 & 0 & 0 & $\mathrm{~g} \mathrm{~m}^{-3}$ \\
\hline Coal gas & 0.080 & 0.800 & $0.088^{5}$ & 0.160 & 0 & 0.240 & 0.170 & 0 & 0 & $\mathrm{~g} \mathrm{~m}^{-3}$ \\
\hline Coal gas BS & 0.008 & 0.800 & $0.088^{5}$ & 0.160 & 0 & 0.240 & 0.150 & 0 & 0 & $\mathrm{~g} \mathrm{~m}^{-3}$ \\
\hline
\end{tabular}

${ }^{*}$ The values are used for different regions. Sources are from Jiang and Tang (2002) except for ${ }^{1}$ UK NAEI (2006b); ${ }^{2}$ Wang et al. (2005a); ${ }^{3}$ Reddy and Venkataraman (2002), ${ }^{4}$ Bond et al. (2004), ${ }^{5}$ U.S. EPA (2006a), ${ }^{6}$ Tian et al. (2001), ${ }^{7}$ Cao (2005), and ${ }^{8}$ Cooke et al. (1999).

straw-burning stoves in China. The $\mathrm{PM}_{2.5}$ emission factor is adopted according to the measurement work of Zhu et al. (2005). As no relevant literature for the $\mathrm{PM}_{10}$ emission factor was found, we assume that the value of the $\mathrm{PM}_{10}$ emission factor is twice as much as that of the $\mathrm{PM}_{2.5}$ in this study. The EC and OC emission factors are given based on analyses of literature (Andreae and Merlet, 2001; Cao, 2005; Cooke et al., 1999; Jenkins et al., 1996; Reddy and Venkataraman, 2002; Streets et al., 2001) (Table 8).

\subsubsection{Solvent and oil evaporation}

The evaporation of paint solvents and petroleum products is an important source of VOC in the atmosphere. The VOC emission factors measured in the work of Jiang and Tang (2002) have been adopted in this study (Table 7). Organic solvent is assumed to take up $50 \%$ of the solvent-based paints, i.e. $500 \mathrm{~g}$ VOC can evaporate from $1 \mathrm{~kg}$ paints. The VOC emission factors for the evaporation of petroleum products are also used in our emission estimates (Table 9).

\subsubsection{Fertilizer application}

Ammonia is emitted into the atmosphere mainly from animals, fertilizer production, soil fertilization, and man. Several kinds of animals are considered in our estimates of $\mathrm{NH}_{3}$ emissions, and the emission factors of typical animals are shown in Table 10. The $\mathrm{NH}_{3}$ emission factor for soil fertilization is determined mainly by the amount of fertilizers, their types and application ways and soil characters according to the work of Sun and Wang (1997) (Table 7). Note that a lower $\mathrm{NH}_{3}$ emission factor $\left(0.17 \mathrm{~g} \mathrm{~g}^{-1}\right)$ for soil fertilization was used to estimate $\mathrm{NH}_{3}$ emissions in the Yangtze Delta (Dong et al., 2009). Such difference can be attributed to both the difference in soil character between different regions and the large uncertainty in measurements.

\subsubsection{Traffic}

China began to implement the National I Standard (referring to Euro I Standard) for automobile exhaust emissions in 1999, National II Standard (referring to Euro II Standard) in 2003, and National III Standard (referring to Euro III Standard) in 2006. Beijing does better in air quality control, with National II Standard implemented in 2002 and National III Standard implemented in 2005. The $\mathrm{SO}_{2}$ emission factors for traffic are determined by the product of the sulfur content of various fuel types and the fuel usage per kilometer. The ratio of the large passenger and heavy goods vehicles using gasoline to those using diesel fuel is $1: 9$, and the ratio of the middle passenger and heavy goods vehicles using gasoline to those using diesel fuel is 1:3. These statistical 
Table 7. Emission factors for industrial processing and other civil activities.

\begin{tabular}{|c|c|c|c|c|c|c|c|c|c|c|}
\hline Activities & $\mathrm{SO}_{2}$ & $\mathrm{NO}_{\mathrm{x}}$ & VOC & $\mathrm{CO}$ & $\mathrm{NH}_{3}$ & $\mathrm{PM}_{10}$ & $\mathrm{PM}_{2.5}$ & $\mathrm{EC}$ & $\mathrm{OC}$ & Units \\
\hline \multicolumn{11}{|c|}{ Industrial Processing } \\
\hline Fertilizer & 0 & 0 & 0 & 0 & $5.00^{9}$ & $0.400^{10}$ & $0.040^{10}$ & $0.008^{3}$ & $0.016^{3}$ & $\mathrm{~g} \mathrm{~kg}^{-1}$ \\
\hline Sulfuric acid & $6.75^{10}$ & 0 & 0 & 0 & 0 & $0.375^{10}$ & $0.375^{10}$ & $0.008^{3}$ & $0.016^{3}$ & $\mathrm{~g} \mathrm{~kg}^{-1}$ \\
\hline Amonia & $3.00^{10}$ & $0.900^{10}$ & 0 & $0.030^{10}$ & $1.00^{9}$ & 0 & 0 & 0 & 0 & $\mathrm{~g} \mathrm{~kg}^{-1}$ \\
\hline Cement & 0.043 & 1.037 & $0.012^{5}$ & $22.9^{2}$ & 0 & 0.801 & 0.401 & $0.0813^{3}$ & $0.271^{3}$ & $\mathrm{~g} \mathrm{~kg}^{-1}$ \\
\hline Sintering & 0.850 & 0 & 0 & $22.0^{2}$ & 0 & 0.270 & 0.190 & 0 & 0 & $\mathrm{~g} \mathrm{~kg}^{-1}$ \\
\hline Iron & 0.070 & 0 & 0 & $40.5^{2}$ & 0 & 0.160 & 0.080 & $0.0162^{3}$ & $0.0541^{3}$ & $\mathrm{~g} \mathrm{~kg}^{-1}$ \\
\hline Steel & 2.53 & 0 & 0 & $46.1^{2}$ & 0 & $0.140^{11}$ & $0.130^{11}$ & $0.0264^{3}$ & $0.0878^{3}$ & $\mathrm{~g} \mathrm{~kg}^{-1}$ \\
\hline Rolled steel & 0.430 & 0 & 0 & 0 & 0 & 0.046 & 0.046 & 0 & 0 & $\mathrm{~g} \mathrm{~kg}^{-1}$ \\
\hline Coke & 0.910 & 1.23 & 0 & 6.66 & 0 & 1.45 & 1.20 & $0.600^{12}$ & $0.430^{12}$ & $\mathrm{~g} \mathrm{~kg}^{-1}$ \\
\hline Crude oil & $3.62^{6}$ & $0.560^{6}$ & $0.459^{5}$ & 0 & 0 & 0 & 0 & 0 & 0 & $\mathrm{~g} \mathrm{~kg}^{-1}$ \\
\hline Paints & 0 & 0 & $15.0^{5}$ & 0 & 0 & 0 & 0 & 0 & 0 & $\mathrm{~g} \mathrm{~kg}^{-1}$ \\
\hline Vegetable oil & 0 & 0 & $3.70^{5}$ & 0 & 0 & 0 & 0 & 0 & 0 & $\mathrm{~g} \mathrm{~kg}^{-1}$ \\
\hline \multicolumn{11}{|c|}{ Other Civil Activities } \\
\hline Central heating & $10.0-15.38^{*}$ & 4.00 & $0.032^{1}$ & $15.0^{2}$ & 0 & 1.61 & 0.74 & $0.150^{4}$ & $0.500^{4}$ & $\mathrm{~g} \mathrm{~kg}^{-1}$ \\
\hline Oil \& paints & 0 & 0 & 500 & 0 & 0 & 0 & 0 & 0 & 0 & $\mathrm{~g} \mathrm{~kg}^{-1}$ \\
\hline Cooking & 0 & 0 & 1.04 & 0 & 0 & 1.18 & 0.701 & 0 & 0 & $\mathrm{~g} \mathrm{~kg}^{-1}$ \\
\hline Man & 0 & 0 & 0 & 0 & $1.30^{9}$ & 0 & 0 & 0 & 0 & $\mathrm{~kg} / \mathrm{yr}$ \\
\hline Soil fertilization & 0 & 0 & 0 & 0 & $0.291^{9}$ & 0 & 0 & 0 & 0 & $\mathrm{~g} \mathrm{~g}^{-1}$ \\
\hline Traffic dust & 0 & 0 & 0 & 0 & 0 & 0.784 & 0.332 & 0 & 0 & $\mathrm{~g} \mathrm{~km}^{-1}$ \\
\hline
\end{tabular}

Sources are the same as in Table 6 except for ${ }^{9}$ Sun and Wang (1997), ${ }^{10}$ UNEP (1996), ${ }^{11}$ Zhang et al. 2006), and ${ }^{12}$ Bond et al. (2004) and Streets et al. (2001).

Table 8. Emission factors for crop straw burning (units: $\mathrm{g} \mathrm{kg}^{-1}$ ).

\begin{tabular}{lrrrrrrrrr}
\hline Crop Straw & $\mathrm{SO}_{2}$ & $\mathrm{NO}_{\mathrm{x}}$ & $\mathrm{VOC}$ & $\mathrm{CO}$ & $\mathrm{NH}_{3}$ & $\mathrm{PM}_{10}$ & $\mathrm{PM}_{2.5}$ & $\mathrm{EC}$ & $\mathrm{OC}$ \\
\hline Wheat & $0.530^{13}$ & $1.29^{13}$ & $3.5^{14}$ & $61.1^{14}$ & 0 & $60.1^{15}$ & $30.05^{15}$ & $0.84^{16}$ & $3.02^{16}$ \\
Corn & $0.530^{13}$ & $1.29^{13}$ & $2.93^{14}$ & $40.3^{14}$ & 0 & $47.4^{15}$ & $23.7^{15}$ & $0.83^{16}$ & $2.01^{16}$ \\
Rice & $0.530^{13}$ & $1.29^{13}$ & $9.39^{14}$ & $48.7^{14}$ & 0 & $19.6^{15}$ & $9.80^{15}$ & $0.63^{16}$ & $1.07^{16}$ \\
Cotton & $0.630^{13}$ & $0.700^{13}$ & $0.141^{14}$ & $23.6^{14}$ & 0 & $20.0^{17}$ & $10.0^{17}$ & $0.82^{7}$ & $1.83^{7}$ \\
Oil & $0.530^{13}$ & $1.29^{13}$ & $8.49^{14}$ & $65.6^{14}$ & 0 & $25.2^{18}$ & $12.6^{18}$ & $1.00^{20}$ & $3.55^{20}$ \\
Other & $0.530^{13}$ & $1.29^{13}$ & $2.93^{14}$ & $40.3^{14}$ & 0 & $24.0^{19}$ & $12.0^{19}$ & $1.00^{20}$ & $3.55^{20}$
\end{tabular}

Sources are from ${ }^{13}$ Tian et al. (2002), ${ }^{14}$ Zhu (2004), ${ }^{15}$ Zhu et al. (2005), ${ }^{16}$ Cao (2005), Cooke et al. (1999), Jenkins et al. (1996), and Streets et al. (2001); ${ }^{17}$ Fine et al. (2001), 18 Crutzen and Andreae (1990), ${ }^{19}$ Seiler and Crutzen (1980), ${ }^{20}$ Reddy and Venkataraman (2002), Streets et al. (2001), Jenkins et al. (1996), and Andreae and Merlet (2001).

data are used in our calculations of the $\mathrm{CO}$ emission factors for the passenger and goods vehicles. Table 11 gives a list of the emission factors for motor vehicles used in our inventory. These parameters are determined mostly according to the local measurements as reported by literature (e.g. Jiang and Tang, 2002; Cao, 2005; Li et al., 2003b; Wang, 2002) and partly refer to the experimental results abroad (e.g. Reddy and Venkataraman, 2002).

\section{Results}

\subsection{Emissions by province and sector}

Table 12 and Table 13 show the calculated anthropogenic emissions in the larger Huabei region in the year 2003 by sector (Table 12) and by province (Table 13), respectively. The percent contributions to the total emissions of different pollutants in the region are shown in Fig. 2 for each sector of the region and in Fig. 3 for each sector of the provinces. Although our estimates are based on various sectors, we provide a gridded emission inventory only for four sectors, i.e. industrial, civil, traffic, and straw burning. The industrial 
Table 9. VOC emission factors of oil depot.

\begin{tabular}{lccccc}
\hline Type & $\begin{array}{c}\text { Breath Coefficient } \\
\left(\mathrm{kg} \mathrm{m}^{-3} \mathrm{yr}^{1}\right)\end{array}$ & $\begin{array}{c}\text { Working } \\
\text { Loss }\left(\mathrm{g} \mathrm{kg}^{-1}\right)\end{array}$ & $\begin{array}{c}\text { Submerged } \\
\text { Discharge }\left(\mathrm{g} \mathrm{kg}^{-1}\right)\end{array}$ & $\begin{array}{c}\text { Splashed } \\
\text { Discharge }\left(\mathrm{g} \mathrm{kg}^{-1}\right)\end{array}$ & $\begin{array}{c}\text { Discharge in } \\
\text { Average }\left(\mathrm{g} \mathrm{kg}^{-1}\right)\end{array}$ \\
\hline Gasoline & 7.01 & 1.36 & 1.08 & 1.95 & 1.52 \\
Disele Oil & Neglected & 0.017 & 0.014 & 0.024 & 0.019 \\
\hline
\end{tabular}

Sources are from Jiang and Tang (2002).

Table 10. Ammonia emission factors of animals (units: $\mathrm{kg} \mathrm{yr}^{-1}$ ).

\begin{tabular}{lccccc}
\hline Animals & Cow & Horse & Pig & Sheep & Poultry \\
\hline $\mathrm{NH}_{3}$ & $21.0^{21}$ & $16.9^{9}$ & $5.0^{21}$ & $3.10^{21}$ & $0.250^{21}$ \\
\hline
\end{tabular}

Sources are from ${ }^{9}$ Sun and Wang (1997) and ${ }^{21}$ Van Aardenne (2002).

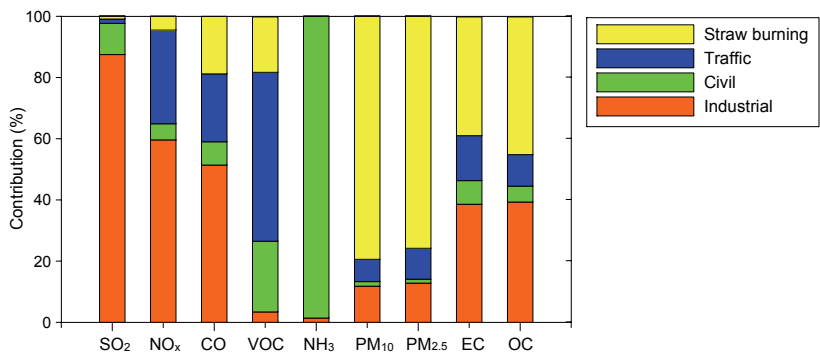

Fig. 2. Percent contributions from different sectors to the total emissions in the larger Huabei region for the year 2003.

sector includes the power generation, industrial energy, industrial processing, and the civil sector includes civil energy (including central heating), oil and solvents, and manure. Power generation is an important emission source and was generally considered as a separate sector in previous inventories (e.g. Zhang et al., 2009). In our inventory, the industrial sector is further separated into the industrial area and point sub-sectors, with the most important emission sources (e.g. large power plants) provided specifically. Therefore, the power generation sector is not given as a sector in our gridded emission inventory. Straw burning for heating and cooking might be considered as a part of the residential sector in other inventories (Zhang et al., 2009). In this study straw burning is treated as one sector exclusively, mainly because it has unique emission factors and its activities occur in the countryside. This separation strategy may be useful for emission updates and model applications in the future.

\subsection{1 $\mathrm{SO}_{2}$}

The total $\mathrm{SO}_{2}$ emission is estimated to be $9.55 \mathrm{Tg}$ in the larger Huabei region $(4.73 \mathrm{Tg}$ in the Huabei administrative region) in the year 2003. Coal burning makes a dominant
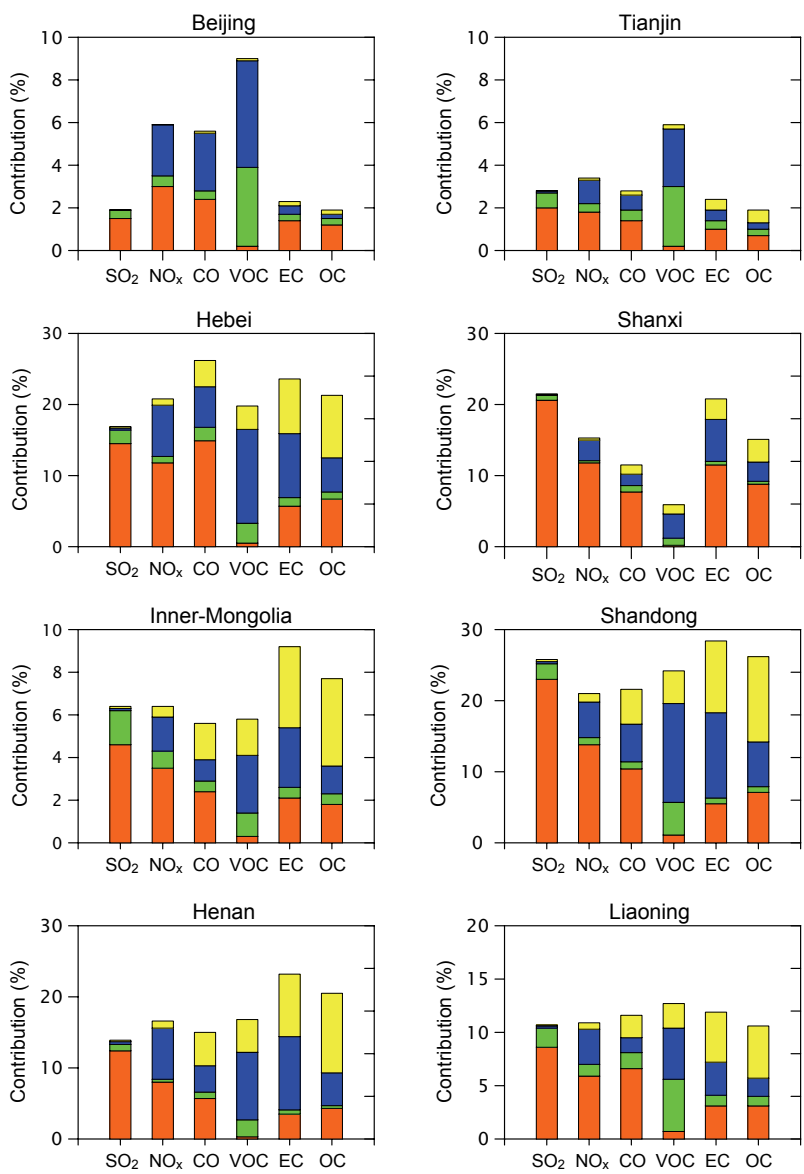

Fig. 3. Percent contributions from each province to the total emissions in the larger Huabei region for the year 2003. Different colours refer to the same sectors as indicated in Fig. 2.

contribution $(\sim 83 \%)$ of the total $\mathrm{SO}_{2}$ emission, with $12 \%$ for power generation, $61 \%$ for industrial energy, and $10 \%$ for civil energy. In addition, the amount of $\mathrm{SO}_{2}$ produced during industrial processing, e.g. the sintering and smelting of iron minerals during steel production, is also considerable, comprising $\sim 15 \%$ in the total $\mathrm{SO}_{2}$ emission. Shandong is a developed province in economy with a huge amount of energy consumed, mostly from coal burning. Shanxi is a developed province in coal industry with many power generation and coking enterprises. Therefore, Shandong and Shanxi are 
Table 11. Emission factors for motor vehicles (units: $\mathrm{g} \mathrm{km}^{-1}$ ).

\begin{tabular}{|c|c|c|c|c|c|c|c|c|c|c|}
\hline Vehicles & $\mathrm{SO}_{2}$ & $\mathrm{NO}_{\mathrm{X}}$ & VOC & $\mathrm{CO}$ & $\mathrm{NH}_{3}$ & $\mathrm{PM}_{10}$ & $\mathrm{PM}_{2.5}$ & $\mathrm{EC}$ & $\mathrm{OC}$ & Mileage $\left(10^{4} \mathrm{~km} \mathrm{yr}^{-1}\right)$ \\
\hline \multicolumn{11}{|c|}{ Passenger Vehicles } \\
\hline Large & 1.20 & 21.0 & 4.28 & $13.7^{22}$ & 0 & 0.146 & 0.113 & 0.0243 & 0.0191 & 3.00 \\
\hline Middle & 0.800 & 4.61 & 1.51 & $20.4^{22}$ & 0 & 0.140 & 0.110 & 0.0237 & 0.0186 & 2.80 \\
\hline Bus & 1.20 & 10.0 & 1.51 & 5.00 & 0 & 4.34 & 4.15 & 0.891 & 0.702 & 6.57 \\
\hline Small & 0.400 & 1.30 & 7.96 & $21.9^{22}$ & 0 & 0.0153 & 0.0119 & 0.006 & 0.004 & 2.00 \\
\hline Mini & 0.400 & 1.30 & 7.96 & $21.9^{22}$ & 0 & 0.0153 & 0.0119 & 0.006 & 0.004 & 2.00 \\
\hline Taxi & 0.096 & $0.843^{23}$ & 6.08 & $16.9^{23}$ & 0 & 0.0153 & 0.0119 & 0.006 & 0.004 & 9.32 \\
\hline Car & 0.096 & $1.94^{24}$ & 6.08 & $39.8^{25}$ & 0 & 0.0153 & 0.0119 & 0.006 & 0.004 & 2.00 \\
\hline \multicolumn{11}{|c|}{ Goods Vehicles } \\
\hline Heavy & 1.00 & 20.0 & 4.28 & 10.0 & 0 & 4.82 & 4.61 & 0.99 & 0.78 & 3.00 \\
\hline Trailer & 1.60 & 35.0 & 4.28 & 17.5 & 0 & 8.44 & 8.07 & 1.10 & 0.83 & 3.00 \\
\hline Middle & 0.700 & $4.61^{26}$ & 1.51 & $20.4^{22}$ & 0 & 0.140 & 0.110 & 0.023 & 0.018 & 2.80 \\
\hline Light & 0.600 & $2.75^{22}$ & 4.68 & $21.9^{22}$ & 0 & 0.0537 & 0.0417 & 0.021 & 0.016 & 2.00 \\
\hline Farm & 0.120 & $2.75^{22}$ & 4.68 & 53.0 & 0 & 0.0537 & 0.0417 & 0.021 & 0.016 & 1.00 \\
\hline Mini & 0.096 & 0.830 & 6.08 & $16.3^{25}$ & 0 & 0.0153 & 0.0119 & 0.006 & 0.004 & 1.50 \\
\hline \multicolumn{11}{|c|}{ Other Vehicles } \\
\hline Motorcycles & 0.032 & 0.100 & $5.25^{22}$ & 17.0 & 0 & 1.15 & 1.11 & 0.05 & 0.35 & 1.00 \\
\hline Tractors & 0.700 & 4.00 & $1.51^{22}$ & 2.00 & 0 & 1.90 & 1.82 & 1.10 & 0.83 & 0.10 \\
\hline
\end{tabular}

The emission factors of VOC are from Li et al. (2003), and the factors for EC and OC are from Cao (2005), Reddy and Venkataraman (2002), and Wang (2002). Mileage data are from Tang et al. (1999). The rest are from Jiang and Tang (2002) except for ${ }^{22} \mathrm{Li}$ et al. (2003), ${ }^{23}$ Wang et al. (2002), ${ }^{24} \mathrm{Zhao}$ and Ma (2008), and ${ }^{25}$ Yang et al. (2003), ${ }^{26} \mathrm{He}$ et al. (1998).

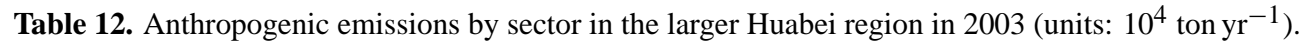

\begin{tabular}{lrrrrrrrrr}
\hline Sectors & $\mathrm{SO}_{2}$ & $\mathrm{NO}_{\mathrm{x}}$ & $\mathrm{NMVOC}$ & $\mathrm{CO}$ & $\mathrm{NH}_{3}$ & $\mathrm{PM}_{10}$ & $\mathrm{PM}_{2.5}$ & $\mathrm{EC}$ & $\mathrm{OC}$ \\
\hline Power generation & 115.6 & 51.4 & 3.51 & 19.4 & 0 & 6.79 & 4.84 & 0.077 & 1.93 \\
Industrial enegery & 578.0 & 187.0 & 3.29 & 593.4 & 0 & 64.9 & 30.5 & 6.29 & 19.0 \\
Civil energy & 97.4 & 28.0 & 0.519 & 355.0 & 0 & 15.8 & 7.49 & 3.17 & 5.13 \\
Industrial processing & 142.0 & 75.7 & 6.37 & 1782.2 & 7.61 & 55.4 & 36.6 & 9.54 & 18.0 \\
Straw burning & 10.1 & 24.0 & 69.1 & 876.2 & 0 & 854.7 & 427.3 & 16.0 & 44.6 \\
Oil and solvents & 0 & 0 & 87.9 & 0 & 0 & 0 & 0 & 0 & 0 \\
Manure & 0 & 0 & 0 & 0 & 527.7 & 0 & 0 & 0 & 0 \\
Traffic & 13.4 & 161.2 & 210.9 & 1033.5 & 0 & 78.9 & 56.5 & 6.06 & 10.2 \\
\hline Total & 955 & 527 & 382 & 4658 & 535 & 1074 & 562 & 41 & 99 \\
\hline
\end{tabular}

larger $\mathrm{SO}_{2}$ emission sources than the other administrative regions in larger Huabei. Nevertheless, Tianjin is the administrative region with the highest $\mathrm{SO}_{2}$ emission strength (the emission rates per unit area) due to many power and steel plants there.

\subsubsection{NO $_{\mathrm{x}}$}

The total $\mathrm{NO}_{\mathrm{x}}$ emission is estimated to be $5.27 \mathrm{Tg}$ in the larger Huabei region $(2.72 \mathrm{Tg}$ in the Huabei administra- tive region) in the year 2003. The estimated regional $\mathrm{NO}_{2}$ emissions are about 2-3\% (administrative Huabei region) or $5 \%$ (larger Huabei region) of the global anthropogenic $\mathrm{NO}_{2}$ emissions. Coal burning makes a major contribution $(\sim 50 \%)$ to the total $\mathrm{NO}_{\mathrm{x}}$ emissions, with up to $10 \%$ for power generation, $35 \%$ for industrial energy, and $5 \%$ for civil energy. The industrial processing and traffic sectors contribute $14 \%$ and $31 \%$ to the total $\mathrm{NO}_{\mathrm{x}}$ emissions in the larger Huabei region, respectively. Industrial activity (energy and processing together) makes a $50 \%$ contribution to the 
Table 13. Anthropogenic emissions by province in the larger Huabei region in 2003 (units: $10^{4}$ ton $_{\mathrm{yr}^{-1}}$ ).

\begin{tabular}{|c|c|c|c|c|c|c|c|c|c|c|}
\hline No. & Administrative region & $\mathrm{SO}_{2}$ & $\mathrm{NO}_{\mathrm{x}}$ & NMVOC & $\mathrm{CO}$ & $\mathrm{NH}_{3}$ & $\mathrm{PM}_{10}$ & $\mathrm{PM}_{2.5}$ & EC & $\mathrm{OC}$ \\
\hline 1 & Beijing & 18.7 & 30.9 & 34.6 & 258.0 & 8.7 & 16.8 & 9.0 & 2.45 & 2.60 \\
\hline 2 & Tianjin & 25.9 & 17.7 & 22.4 & 132.6 & 7.4 & 18.6 & 10.0 & 0.982 & 2.12 \\
\hline 3 & Hebei & 162.2 & 109.2 & 75.7 & 1220.2 & 103.1 & 229.1 & 121.4 & 7.95 & 21.2 \\
\hline 4 & Shanxi & 205.7 & 80.7 & 22.4 & 536.9 & 34.7 & 98.1 & 52.4 & 6.62 & 12.9 \\
\hline 5 & Inner-Monglia & 60.8 & 33.1 & 21.9 & 266.7 & 49.3 & 94.6 & 49.0 & 2.93 & 6.99 \\
\hline 6 & Shandong & 245.7 & 110.6 & 92.5 & 1008.9 & 134.3 & 268.4 & 138.7 & 8.41 & 24.1 \\
\hline 7 & Henan & 133.5 & 87.4 & 64.3 & 694.8 & 147.3 & 228.4 & 119.5 & 7.48 & 18.8 \\
\hline \multirow[t]{2}{*}{8} & Liaoning & 102.8 & 57.4 & 48.6 & 540.4 & 50.8 & 120.3 & 62.1 & 4.39 & 10.3 \\
\hline & Total & 955 & 527 & 382 & 4658 & 535 & 1074 & 562 & 41 & 99 \\
\hline
\end{tabular}

total $\mathrm{NO}_{\mathrm{x}}$ emission in the region. Straw burning makes a relatively small contribution $(\sim 5 \%)$ to the total $\mathrm{NO}_{\mathrm{x}}$ emission in larger Huabei. Shandong and Hebei have higher $\mathrm{NO}_{\mathrm{x}}$ emission sources than the other administrative regions in larger Huabei. There are many power, steel, coking, and petroleum plants as well as motor vehicles in Hebei Province. The emission strength of $\mathrm{NO}_{\mathrm{x}}$ is very strong in Beijing and Tianjin mainly due to numerous automobiles accumulated in small areas.

\subsubsection{VOC}

The total anthropogenic VOC emission is estimated to be $3.82 \mathrm{Tg}$ in the larger Huabei region $(1.77 \mathrm{Tg}$ in the Huabei administrative region) in the year 2003, with a predominant contribution $(\sim 96 \%)$ from non-industrial activities. Traffic makes a major contribution (55\%) to the total VOC emission, and the contributions of other non-industrial activities are $23 \%$ for evaporation of oil and paint solvents, and $18 \%$ for straw burning. General industrial activities including power generation, industrial energy and industrial processing, make a small contribution $(\sim 3 \%)$ to the total VOC emission in larger Huabei. The VOC emissions in Shandong are the largest because of many traffic, straw-burning, and crude oil-processing activities. The emission strength of VOC in Beijing and Tianjin is very strong mainly due to the highly concentrated number of vehicles.

\subsubsection{CO}

The total CO emission is estimated to be $46.59 \mathrm{Tg}$ in the larger Huabei region (24.14 Tg in the Huabei administrative region) in the year 2003. The contributions are from industrial processing (38\%), traffic (22\%), straw burning (19\%), industrial energy (13\%) and civil energy (8\%), respectively. Large amounts of $\mathrm{CO}$ can be emitted during industrial processing in the coke, steel, and cement production. Industrial activities, including industrial energy and industrial processing together make a dominant contribution $(51 \%)$ to the to- tal CO emission in larger Huabei. The contribution of coal burning to the total $\mathrm{CO}$ emission is about $21 \%$. Hebei is the largest $\mathrm{CO}$ emission source in larger Huabei, followed by Shandong.

\subsection{5 $\mathrm{NH}_{3}$}

The total $\mathrm{NH}_{3}$ emission is estimated to be $5.36 \mathrm{Tg}$ in the larger Huabei region (2.03 Tg in Huabei) in the year 2003. The contribution of manure to the total $\mathrm{NH}_{3}$ emission is predominant ( $\sim 98 \%$ ), with $48 \%$ from animals, $41 \%$ from agricultural fertilizers, and $9 \%$ from man, respectively. As both agricultural and animal husbandry activities are strong in Henan, Shandong and Hebei, these three provinces together are the main sources $(56 \%)$ of the total $\mathrm{NH}_{3}$ emission in the larger Huabei region.

\subsection{6 $\mathrm{PM}_{10}$ and $\mathrm{PM}_{2.5}$}

The total anthropogenic $\mathrm{PM}_{10}$ and $\mathrm{PM}_{2.5}$ emissions are estimated to be $10.74 \mathrm{Tg}$ and $5.62 \mathrm{Tg}$ in the larger Huabei region ( $4.57 \mathrm{Tg}$ and $2.42 \mathrm{Tg}$ in the Huabei administrative region) in the year 2003, respectively. Note that the particle sources from building construction and natural dust are not taken into account in this study. The sources from straw burning are the strongest, contributing $80 \%$ and $76 \%$ of the total $\mathrm{PM}_{10}$ and $\mathrm{PM}_{2.5}$ emissions, respectively. The traffic sector with traffic blowing dust included contributes $7 \%$ of the total $\mathrm{PM}_{10}$ and $10 \%$ of the total $\mathrm{PM}_{2.5}$, and the industrial energy and processing together contributes $11 \%$ of the total $\mathrm{PM}_{10}$ and $12 \%$ of the total $\mathrm{PM}_{2.5}$, respectively. Shandong is the largest $\mathrm{PM}_{10}$ and $\mathrm{PM}_{2.5}$ emission source in the larger Huabei, and followed are Hebei and Henan. Tianjin is the second with respect to the emission strength followed by Shandong.

\subsubsection{EC and OC}

The total EC and OC emissions are estimated to be $0.41 \mathrm{Tg}$ and $0.99 \mathrm{Tg}$ in the larger Huabei region $(0.21 \mathrm{Tg}$ and $0.46 \mathrm{Tg}$ in the Huabei administrative region) in the year 2003, 
respectively. The industrial sector contributes $38 \%$ and $37 \%$ of the total EC and OC emissions, respectively. The contributions from straw burning are $39 \%$ and $45 \%$. The traffic sector contributes $15 \%$ and $10 \%$, respectively, to EC and OC. Shandong is the largest EC and OC emission source in the larger Huabei followed by Hebei and Henan. The emission strength of EC and OC in Beijing and Tianjin are very high compared to other provinces.

\subsection{Spatially gridded emissions}

Figure 4 shows the spatial distributions of primary pollutant emissions in larger Huabei in 2003 at a $0.1^{\circ}$ latitude $\times 0.1^{\circ}$ longitude resolution. The polluted areas in Huabei are clearly visible with 1-2 order of magnitude higher emission rates in the central and southern Huabei (e.g. $1-10 \mathrm{Gg} \mathrm{yr}^{-1}$ per grid for $\mathrm{SO}_{2}$ and $\mathrm{NO}_{\mathrm{x}}$ ) than those in the northern Huabei (e.g. $\sim 0.1 \mathrm{Gg} \mathrm{yr}^{-1}$ per grid for $\mathrm{SO}_{2}$ and $\mathrm{NO}_{\mathrm{x}}$ ). Three major emission source areas can be identified in the region: the first is the larger Beijing-Tianjin-Tangshan area in the northern parts of Hebei Province, the second is the larger ShijiazhuangHandan-Taiyuan area in the south parts of Hebei Province and the central parts of Shanxi Province, and the third is the larger Zibo-Zaozhuang area in the central and southern parts of Shandong Province. The hot spots due to emissions in the Beijing and Tianjin megacities and other large industrial cities, e.g. Tangshan, Shijiazhuang and Taiyuan, are also clearly visible (e.g. larger than $10 \mathrm{Gg} \mathrm{yr}^{-1}$ per grid for $\mathrm{SO}_{2}$ or $\mathrm{NO}_{\mathrm{x}}$ ). Although the emission spatial distributions of different pollutants are very similar to each other in general, some difference can also be seen. For example, while $\mathrm{SO}_{2}$ has peak emissions (larger than $20 \mathrm{Gg} \mathrm{yr}^{-1}$ per grid) in some industrial cities such as Taiyuan in Shanxi Province, VOC has peak emissions (larger than $10 \mathrm{Gg} \mathrm{yr}^{-1}$ per grid) in the Beijing and Tianjin megacities, indicating the variations of pollution source types in these different regions.

\subsection{Point source emissions}

Three-hundred-and-forty-five large point sources including power plants, steel plants, cement plants, and other industrial plants in Huabei are included in our inventory. Therefore, our inventory has an advantage in the spatial distributions of the emissions with respect to other inventories. Figure 5 shows the percent contributions of these point sources to the total emissions of primary pollutants in larger Huabei. The point sources contribute $\sim 10-20 \%$ to the total emissions of $\mathrm{SO}_{2}$, $\mathrm{NO}_{\mathrm{x}}, \mathrm{CO}, \mathrm{EC}$ and $\mathrm{OC}$, and $\sim 1-5 \%$ of VOC, $\mathrm{NH}_{3}, \mathrm{PM}_{2.5}$, and $\mathrm{PM}_{10}$. Power plants dominate the contributions to the total $\mathrm{SO}_{2}$ and $\mathrm{NO}_{\mathrm{x}}$ emissions, by $11 \%$ and $8 \%$, respectively. Followed are steel plants, with a contribution of $\sim 6 \%$ for both $\mathrm{SO}_{2}$ and $\mathrm{NO}_{\mathrm{x}}$. Steel plants make a major contribution $(17 \%)$ to the total $\mathrm{CO}$ emission, followed by cement plants (4\%). The steel pants also make large contributions to the total EC and OC emissions, by $7 \%$ and $10 \%$, respectively.
Note that the emissions in industrial processes are also taken into account in the calculations, leading to rather higher $\mathrm{CO}$, EC and OC emissions estimated from steel plants than from power plants. Figure 6 presents the percent contributions of the point sources to the $0.1^{\circ}$ latitude $\times 0.1^{\circ}$ longitude gridded emissions of primary pollutants in Huabei. The point sources are widely distributed in the region. Note that for a specific grid the percent contributions from the point source(s) can be rather different for different pollutants, depending on what kind of plant(s) is located in the grid. For example, the contributions to the $\mathrm{SO}_{2}$ and $\mathrm{NO}_{\mathrm{x}}$ emissions in a number of grids can reach up to more than $90 \%$ owing to the large power plants.

\section{Discussions}

\subsection{Comparison with other inventories}

Several global or Asian emission inventories for the period from 2000 to 2006 are available, e.g. EDGAR v3.2 Fast Track 2000 (Olivier et al., 2005), TRACE-P (Streets et al., 20003), and INTEX-B (Zhang et al., 2009). However, these inventories do not provide an emission estimate for the year 2003 specifically. Here we compare our inventory with a global emission inventory for the year 2005, EDGAR-CIRCE, and an Asian emission inventory for the year 2006, INTEX-B. The INTEX-B emission inventory was developed by Zhang et al. (2009) initially for the support of the Intercontinental Chemical Transport Experiment-B campaign in 2006 (Singh et al., 2009). The gridded emissions of INTEX-B were estimated initially by province for China and by country for the rest of Asia with a $0.5^{\circ}$ latitude $\times$ $0.5^{\circ}$ longitude resolution (Zhang et al., 2009). The EDGARCIRCE emission inventory used in this study was prepared in the framework of the CIRCE Project (No. 036961) by the EDGAR group of the EC-Joint Research Center Ispra (Italy), Climate Change Unit (Doering et al., 2009a, b). This dataset includes greenhouse gases, $\mathrm{NO}_{\mathrm{x}}, \mathrm{CO}, \mathrm{VOCs}, \mathrm{NH}_{3}$, and $\mathrm{SO}_{2}$ from fossil fuel and bio fuel related emissions with a $0.1^{\circ}$ latitude $\times 0.1^{\circ}$ longitude resolution. Although emissions are present for the year 1990-2005, only the last year presents monthly specification and has been evaluated with the model EMAC (Pozzer et al., 2011). The emission inventories of EDGAR v3.2 Fast Track (Olivier et al., 2005) and TRACEP (Streets et al., 2003) have not been selected for this study, because they were developed for the emissions in 2000 at a low grid resolution $\left(1^{\circ}\right.$ latitude $\times 1^{\circ}$ longitude). Satellite measurements indicated that pollutant emissions in China increased dramatically from 2000 to 2003 (Richter et al., 2005). Moreover, model studies showed that the TRACE-P inventory underestimates the tropospheric $\mathrm{NO}_{2}$ column density in all the regions of China with respect to the satellite observations (Ma et al., 2006). The TRACE-P inventory was compared with the INTEX-B inventory and revised accordingly (Zhang et al., 2009). 

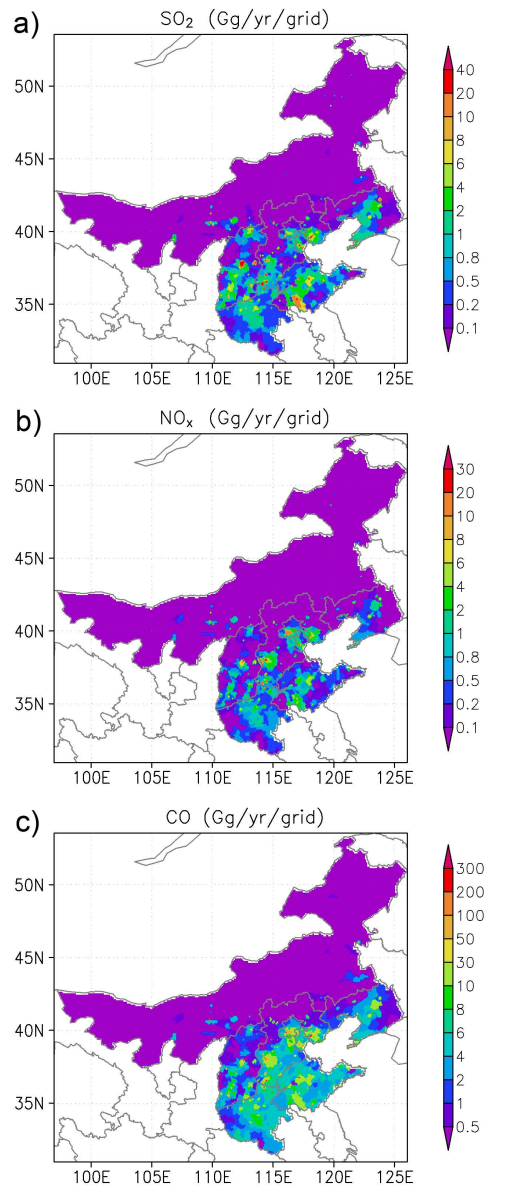
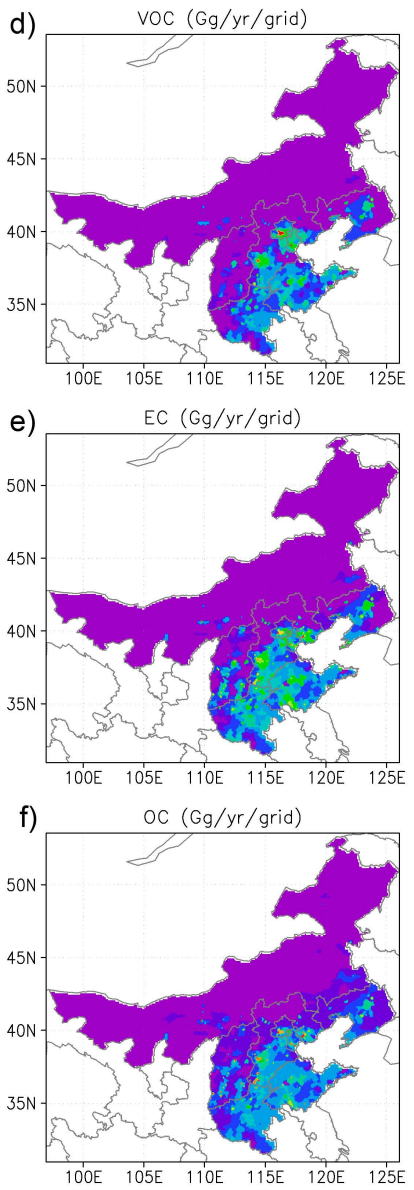
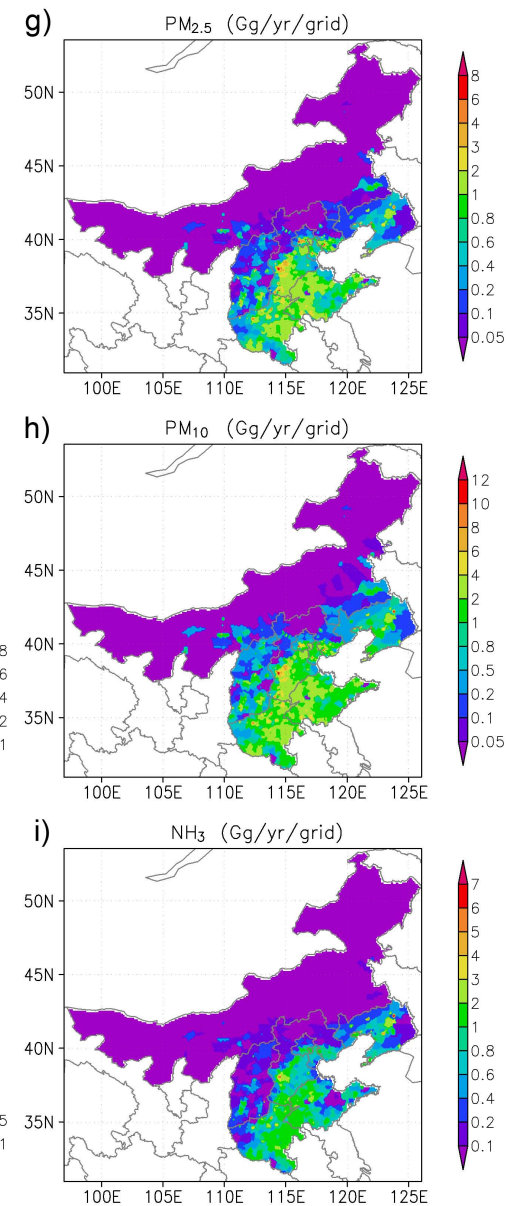

Fig. 4. Spatial distributions of anthropogenic emissions in the larger Huabei region for the year 2003. Units are $\mathrm{Gg} \mathrm{yr}^{-1}$ per grid with a cell size of $0.1^{\circ}$ latitude $\times 0.1^{\circ}$ longitude. Data are available in the Supplement.

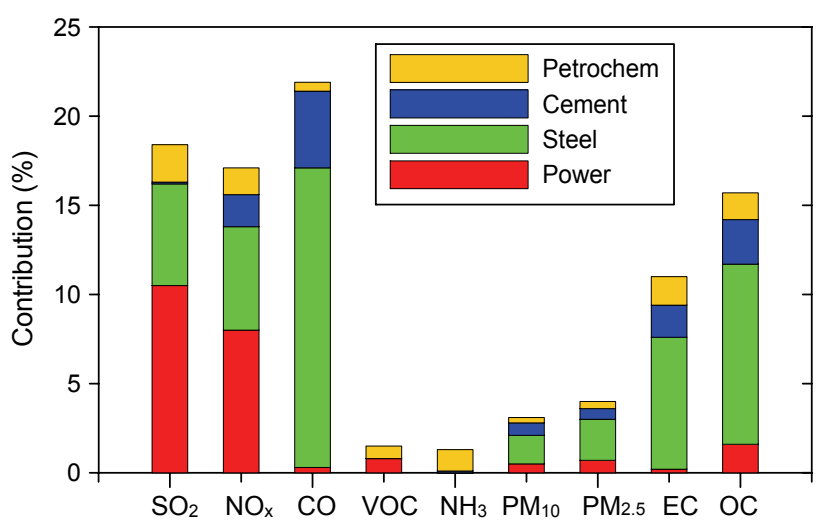

Fig. 5. Percent contributions of the point sources to the total emissions in the larger Huabei region for the year 2003. Different colours refer to power plants, steel plants, cement plants, and petrochemical plants, respectively.
Figure 7 presents the spatial distributions of major pollutant emissions in Huabei estimated by our 2003 inventory (denoted as IPAC-NC), the 2005 EDGAR-CIRCE inventory (denoted as EDGAR), and the 2006 INTEX-B inventory (denoted as INTEX-B), and Fig. 8 shows the emission ratios of IPAC-NC to EDGAR and IPAC-NC to INTEX$\mathrm{B}$ for each $0.1^{\circ}$ latitude $\times 0.1^{\circ}$ longitude grid cell. Note that with respect to Fig. 4 we select a smaller Huabei region including Beijing, Tianjin, Hebei, Shanxi, Shandong, and parts of Inner-Mongolia, Henan and Liaoning for the comparison. Although the IPAC-NC is generally in agreement with the EDGAR-CIRCE and INTEX-B in the emission distribution patterns, e.g. high emissions in the Huabei Plain and peak emissions in Jing-Jin-Tang, differences are present. The EDGAR-CIRCE and INTEX-B inventories provide more homogeneously distributed emissions. They underestimate the emissions in two highly-polluted areas (the larger Shijiazhuang-Handan-Taiyuan area in Hebei and Shanxi Provinces and the larger Zibo-Zaozhuang area in Shandong Provinces) other than Jing-Jin-Tang and overestimate the emissions in the background areas located in the 

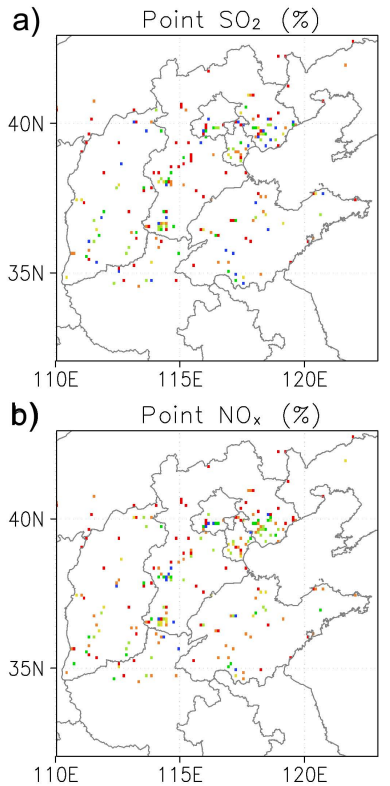

c) Point $\mathrm{CO}(\%)$

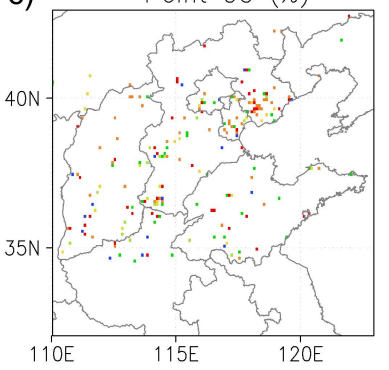

d)

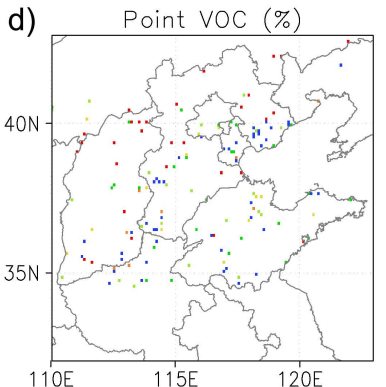

e)

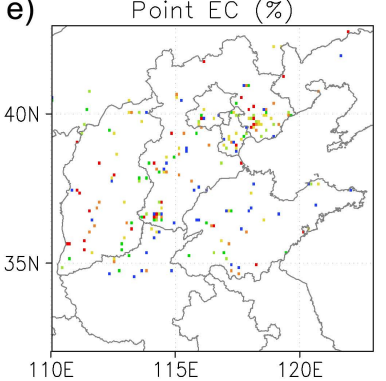

f)
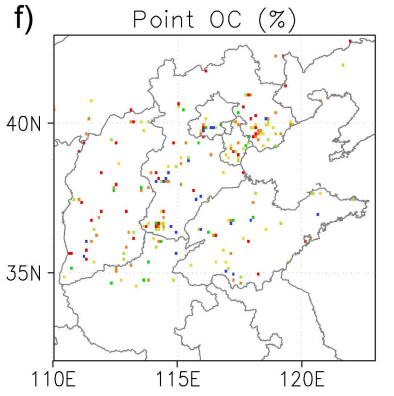

g) Point $\mathrm{PM}_{2.5}$ (\%)

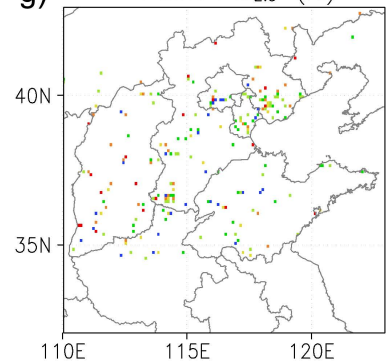

h)

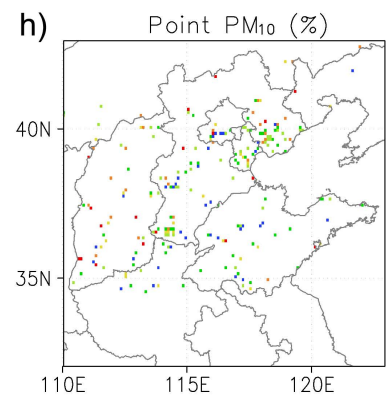

i)

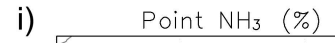

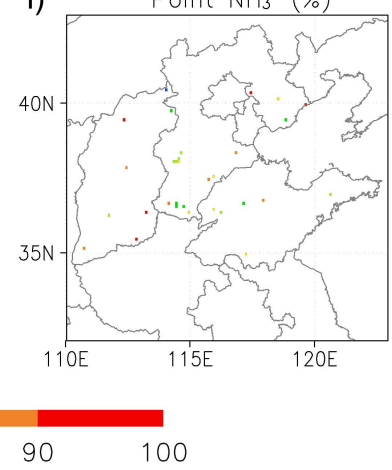

Percent contribution

Fig. 6. Percent contributions of the point sources to the total emissions in each grid $\left(0.1^{\circ}\right.$ latitude $\times 0.1^{\circ}$ longitude $)$ in Huabei for the year 2003.

north and northwest of Huabei. It should be noted that "underestimate" or "overestimate" is with respect to the dataset compared and we cannot establish which inventory is the correct (or closer to reality) in the present study. Compared to the IPAC-NC inventory, EDGAR-CIRCE estimates more small hot spots, i.e. higher emissions from small cities, due to the distribution of the emissions based on power plant presence and population density. While IPAC-NC underestimates pollutant emissions in relative clean rural and background areas such as Inner-Mongolia region, strong point sources considered in IPAC-NC are clearly visible as shown in Fig. 8.

The total emissions in the smaller Huabei region estimated by the three inventories are shown in Fig. 9. For the purpose of comparison, the INTEX-B emissions are distributed into the same finer grid cells $\left(0.1^{\circ}\right.$ latitude $\times 0.1^{\circ}$ longitude $)$ as the IPAC-NC and EDGAR-CIRCE inventories have. The Huabei region in Fig. 9a refers to all the grid cells in Fig. 7 where the IPAC-NC data are available. For a consistency in comparisons, the EDGAR-CIRCE and INTEX-B emissions in the grid cells where the IPAC-NC has a default value are not taken into account. It can be seen that except for $\mathrm{SO}_{2}$ the IPAC-NC and EDGAR-CIRCE inventories estimate nearly the same total emissions of major pollutants in the Huabei region. The total emissions estimated by the INTEX-B inventory are generally higher for most pollutants, by a factor of 2 for VOC and 3 for EC. The largest total emission rate of $\mathrm{SO}_{2}$ is estimated by the EDAGR-CIRCE inventory. The Beijing region in Fig. 9b (the Tianjin region in Fig. 9c) refers to the 16 grid cells that have a distance of less than $0.2^{\circ}$ from the city center, i.e. $39.92^{\circ} \mathrm{N}, 116.46^{\circ} \mathrm{E}\left(39.02^{\circ} \mathrm{N}\right.$, $\left.117.02^{\circ} \mathrm{E}\right)$. The total area of these grid cells is smaller than the real area under the jurisdiction of the municipality, but it is representative for the normal size of a megacity. Larger differences exist between the inventories for the Beijing and 

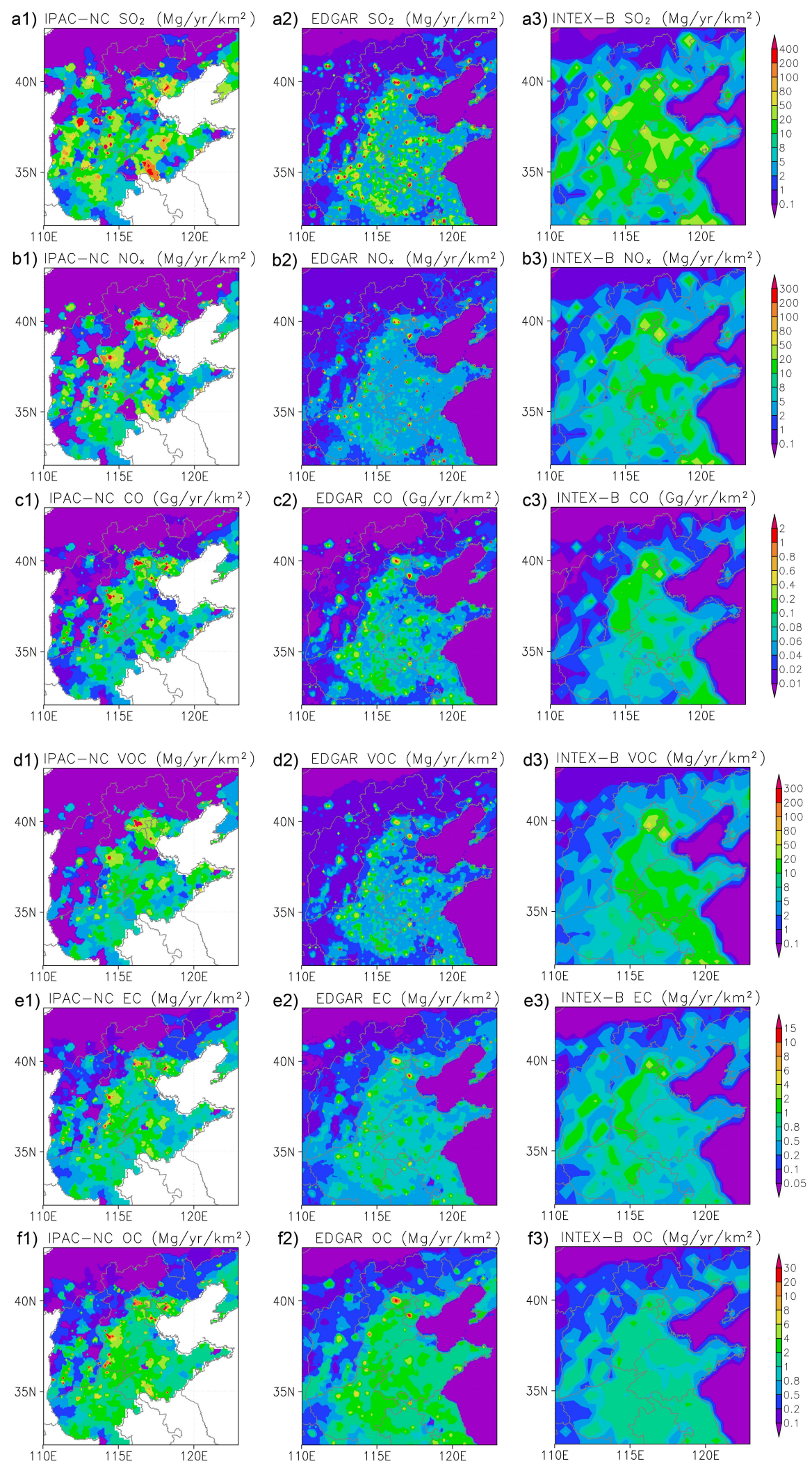

Fig. 7. Comparisons of the 2003 IPAC-NC inventory developed in this study with the 2005 EDGAR-CIRCE inventory and the 2006 INTEX$\mathrm{B}$ inventory in respect of emission distributions in Huabei. Units are $\mathrm{Mg} / \mathrm{yr}$ per square kilometre except for the $\mathrm{CO}$ emission rates, which have a unit of $\mathrm{Gg} \mathrm{yr}^{-1}$ per square kilometre. 

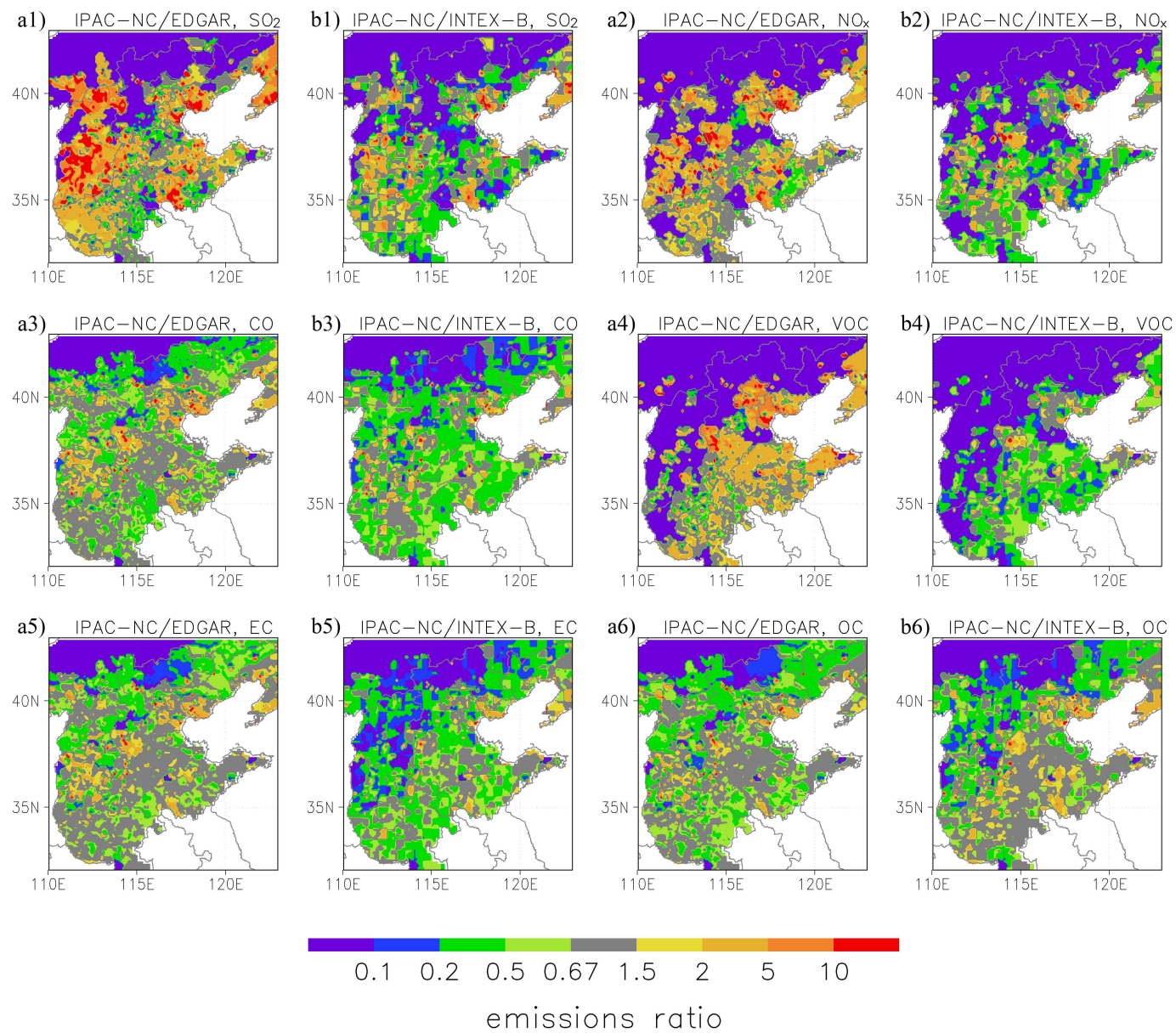

Fig. 8. Spatial distributions of pollutant emission ratios of IPAC-NC to EDGAR (a) and IPAC-NC to INTEX-B (b) based on $0.1^{\circ}$ latitude $\times$ $0.1^{\circ}$ longitude grid cell.

Tianjin areas, in contrast to the Huabei region. For example, IPAC-NC estimates higher emissions of VOC by a factor of 2-3 than the other two inventories, and EDGAR-CIRCE estimates higher emissions of $\mathrm{SO}_{2}$ by a factor of 2-4 than the other two inventories.

\subsection{Uncertainty analysis}

The uncertainties of the national emissions of major air pollutants in China have been estimated based on the uncertainties in emission factors and activity rates (Streets et al., 2003; Zhang et al., 2009; Zhao et al., 2011). For example, the uncertainties of Chinese emissions of $\mathrm{SO}_{2}, \mathrm{NO}_{\mathrm{x}}, \mathrm{EC}$, and $\mathrm{OC}$ in 2005 were estimated to be $-14 \%$ to $13 \%,-13 \%$ to $37 \%$, $-25 \%$ to $136 \%$, and $-40 \%$ to $121 \%$, respectively, according to the work of Zhao et al. (2011) based on Monte Carlo simulations. Such a method was also used to estimate uncertainties in regional inventories, e.g. for the PRD (Zheng et al., 2009b, 2010). For the Chinese inventories, almost all the activity data are from the governmental yearbooks. These statistical data have relatively fewer errors than the emission factors and are very reliable for the emission estimates at the national and provincial levels. Therefore, it has been concluded that the variations in activity rates (e.g. energy consumption or industrial production) are not the main source of emission uncertainties at the national level (Zhao et al., 2011). The uncertainties in emission inventory can also be estimated by comparing different emission inventories for the same region and period (Ma and van Aardenne, 2004). With this method, the uncertainties represented by the bias between existing emission inventories can be estimated at various spatial levels including nation, region, city and gridded cell. An investigation of the distribution of total emissions is also important since distributing the activation rates from provincial levels to local areas and then onto fine grid cells generally results in large bias due to usage of impractical methods, e.g. scaling by population.

In this study, we investigate the differences in emission estimates of our inventory from the EDGAR-CIRCE and INTEX-B inventories. Pollutant emissions in China increased dramatically from 2003 to 2006 (or 2005), as shown in the work of Zhang et al. (2009) for $\mathrm{NO}_{\mathrm{x}}$, Lu et al. (2010) 

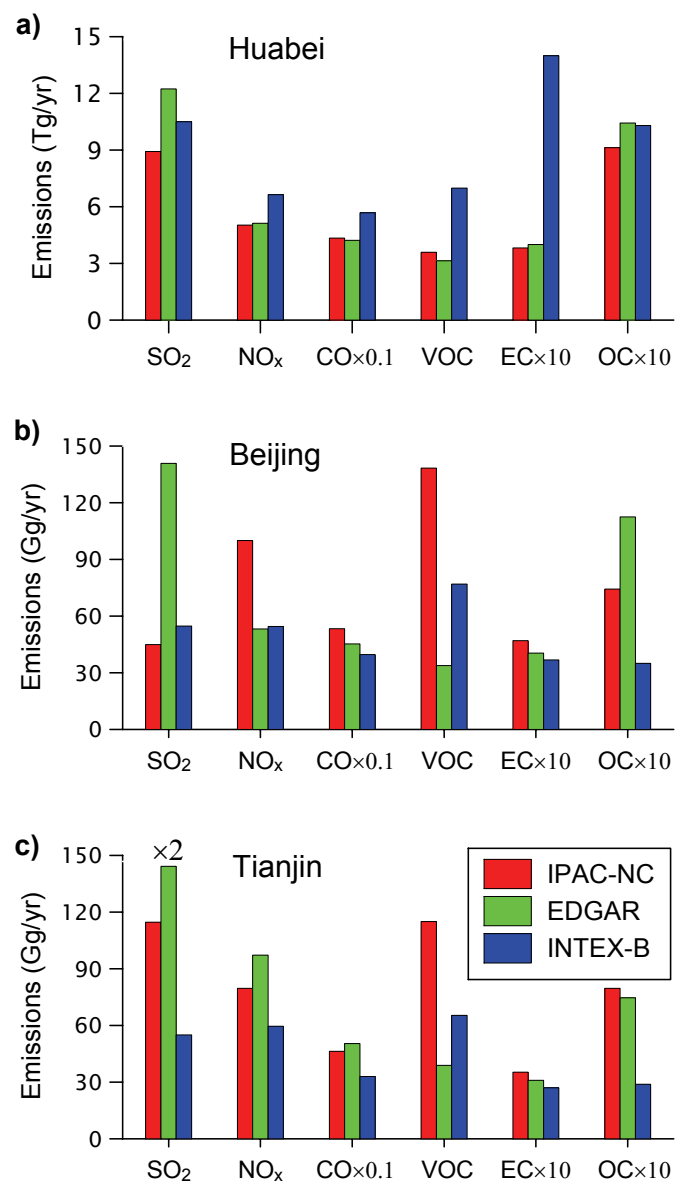

Fig. 9. Comparisons of the 2003 IPAC-NC inventory developed in this study with the 2005 EDGAR-CIRCE inventory and the 2006 INTEX-B inventory in respect of total emissions in the Huabei area (a), the Beijing megacity area (b), and the Tianjin megacity area (c). See the text for detailed descriptions of the areas. Note that different scaling factors are used for $\mathrm{CO}, \mathrm{EC}$ and $\mathrm{OC}$ in all the cases and for $\mathrm{SO}_{2}$ in the EDGAR-CIRCE inventory for the Tianjin area.

for $\mathrm{SO}_{2}$, and Lei et al. (2011) for PM. The activity rates in China changed significantly between 2003 and 2006. For example, from 2003 to 2006 the energy consumption in the larger Huabei increased by $48 \%$, with the coal and gasoline consumption increasing by $42 \%$ and $66 \%$, respectively, (China Statistic Bureau, 2004e). Coal and gasoline dominate the energy supply in industrial and traffic activities, respectively, providing the main sources of most primary pollutants in Huabei. Therefore, we use the ratios of the coal (gasoline) consumption in 2005 and 2006 to the coal (gasoline) consumption in 2003 as indices for the relative increases in the emissions from 2003 to 2005 and 2006. As shown in Fig. 10, the ratios of the EDGAR-CIRCE-2005 and INTEXB-2006 emission rates to the IPAC-NC-2003 emission rate of each pollutant are compared with these relative increase indices for selected regions. Assuming that the same emission
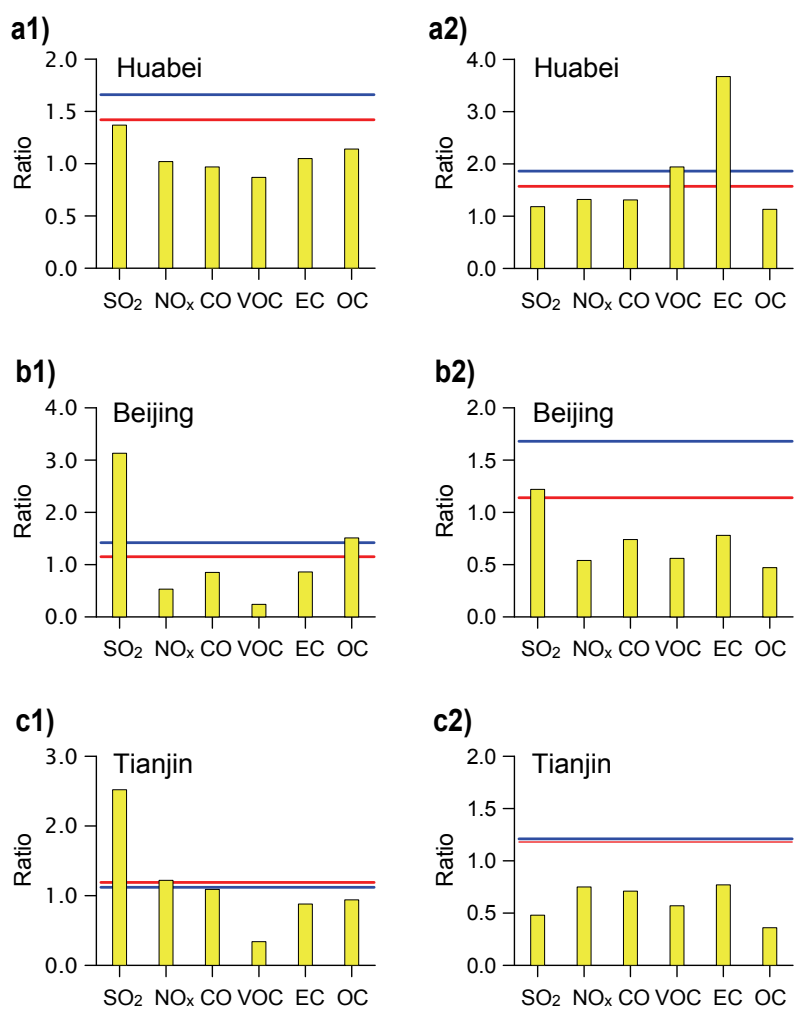

Fig. 10. Ratios of the EDGAR-CIRCE-2005 (1) and INTEX-B2006 (2) emission rates to the IPAC-NC-2003 (reference) emission rate of each pollutant (yellow bars), in comparison with the relative increase in energy use from 2003 to 2005 and 2006, expressed by the ratios of the coal (red lines) and gasoline (blue lines) consumption, in the larger Huabei region (a), the Beijing Municipality (b), and the Tianjin Municipality (c).

factors and the same sources of statistic dataset have been adopted in the inventories, the emission ratios for $\mathrm{SO}_{2}, \mathrm{NO}_{\mathrm{x}}$, $\mathrm{CO}$ and VOC, which are mainly from industrial and traffic activities (Fig. 2), should be close to the relative increase indices. If the relative increase indices are large enough, the emission ratios for $\mathrm{EC}$ and $\mathrm{OC}$ might also be much higher than unit, since more than half of the EC and OC come from industrial and traffic activities (Fig. 2). For example, with the relative increase index values of 1.5 for industrial and traffic activities, the emission ratios for EC and OC could be 1.25, if the straw burning emission would keep constant.

Figure 10a1 and 10a2 show the emission ratios and the relative increase indices for the larger Huabei region in 2005 and 2006, respectively. The relative increase indices for the coal and gasoline consumption in 2005 are 1.42 and 1.66, respectively. The emission ratio of EDGAR-CIRCE-2005 to IPAC-NC-2003 for $\mathrm{SO}_{2}$ is 1.37 in 2005, very close to the relative increase index for the coal consumption, resulting in a bias of less than $+4 \%$ for the total $\mathrm{SO}_{2}$ emission in the 
IPAC-NC inventory with respect to the EDGAR-CIRCE inventory. Not ideally expected, the emission ratios for other pollutants are much lower than the relative increase indices for coal and gasoline consumption. For example, the emission ratios for $\mathrm{NO}_{\mathrm{x}}, \mathrm{CO}$ and $\mathrm{VOC}$ are 1.02, 0.97 and 0.87, respectively. Correspondingly, the biases of the total emissions in the IPAC-NC inventory with respect to the EDGARCIRCE inventory are about $+38 \%$ for $\mathrm{NO}_{\mathrm{x}},+43 \%$ for $\mathrm{CO}$, and $+42 \%$ for VOC. The relative increase indices for coal and gasoline consumption in 2006 are 1.57 and 1.86, respectively. The emission ratios of INTEX-B-2006 to IPAC-NC2003 for $\mathrm{SO}_{2}, \mathrm{NO}_{\mathrm{x}}$ and $\mathrm{CO}$ are lower, with values of 1.18 , 1.32 and 1.31 , respectively. The biases for the total emissions in the IPAC-NC inventory with respect to the INTEX$\mathrm{B}$ inventory are estimated to be about $+28 \%$ for $\mathrm{SO}_{2},+23 \%$ for $\mathrm{NO}_{\mathrm{x}}$, and $+24 \%$ for $\mathrm{CO}$. The emission ratio for $\mathrm{VOC}$ is 1.94, higher than the relative increase index for the gasoline consumption. A bias of $-26 \%$ is estimated for the total VOC emission in the IPAC-NC inventory with respect to the INTEX-B inventory.

The activity rates and emission factors of biomass burning used in the different inventories can be very large. Since a substantial fraction of total EC and OC emissions may originate from biomass burning, it is rather difficult to evaluate the year-to-year variations in EC and OC using the relative increase indices for the coal and gasoline consumption. An extremely high emission ratio of INTEX-B-2006 to IPACNC-2003 for EC is present in Fig. 10a2, with a value of 3.67. Assuming that the total $\mathrm{EC}$ emission from industrial biomass burning keeps constant, a bias of $-76 \%$ is roughly estimated for the total EC emission in the IPAC-NC inventory with respect to the INTEX-B inventory. Above all, except for EC, the biases of the total emissions of most primary air pollutants estimated in our inventory with respect to EDGAR-CIRCE and INTEX-B generally range from $-30 \%$ to $+40 \%$. As can be seen from Fig. 10b-c, much larger biases for the emissions in different areas of the region, e.g. Beijing and Tianjin, are estimated. Even for $\mathrm{SO}_{2}$, which has been thought to have the smallest uncertainty in the Chinese emission estimates (Streets et al., 2003; Zhang et al., 2009; Zhao et al., 2011), the bias between different inventories is very large for Beijing and Tianjin.

Emission factor uncertainties are generally the largest source of uncertainties in the emission estimates. For example, the $\mathrm{SO}_{2}$ emission factors of coal burning used for the power plants in our inventory are $8.46 \mathrm{~g} \mathrm{~kg}^{-1}$ for the larger Jing-Jin-Tang area and $16.56 \mathrm{~g} \mathrm{~kg}^{-1}$ for the rest (see Table 6), which are $55 \%$ lower and $7.5 \%$ higher than the one used in the INTEX-B inventory (ca. $15.4 \mathrm{~g} \mathrm{~kg}^{-1}$, Zhang et al., 2009), respectively. For countries in Asia, implied emission factors from the REAS inventory (Ohara et al., 2007) were selected in the EDGAR-CIRCE inventory. Because $\mathrm{SO}_{2}$ emissions in China depended strongly on the sulfur content of coal, province-by-province data for power plants and other sectors were used in their estimation. Hence, we would expect that the emission factors used in the EDGAR-CIRCE for China are variable by regions, but on average equal to $10.8 \mathrm{~g} \mathrm{~kg}^{-1}$ (plus some reduction factors). The uncertainties due to emission factors are larger for other pollutants like EC and OC; this is mainly due to the wide ranges of emission factors reported in the literature for these pollutants. Note that in our inventory we use a lower value for the EC and OC emission factors than what is used in other inventories. For example, the emission factor of EC used in our inventory is $0.15 \mathrm{~g} \mathrm{~kg}^{-1}$ for industrial coal burning and $0.03 \mathrm{~g} \mathrm{~kg}^{-1}$ for coke production (see Table 6), an order of magnitude lower than the values used in the INTEX-B inventory (ca. $15.4 \mathrm{~g} \mathrm{~kg}^{-1}$, Zhang et al., 2009). However, the uncertainties in the EC emission factors for straw burning $( \pm 20 \%)$ and traffic sectors $( \pm 70 \%)$ are not so large. Note that while the economy and energy use increased dramatically in the 2000s in China, Chinese government has intensified the effort in energy saving and emission reduction since then. Some anti-pollution laws and regulations have been released (e.g. SEPA, 2003). For example, the efforts to reduce the emissions of air pollutants from thermal power plants have been stepped up by using the devices for wet flue gas desulfurization, denitrification and dust removal. These measures have been implemented in different years for different regions, increasing the variability in the emission factors from year to year and the uncertainties in the inventories.

Although monthly emissions are not available in our inventory, we consider the seasonal variation in the estimated emissions by separating the entire year into heating (1 January-15 March and 15 November-31 December) and non-heating (16 March-14 November) periods. Central heating is taken into account only for the heating period. There are large uncertainties in the ratios of the civil coal used and straw burned during the heating period over those during the non-heating period, and we assume a ratio of 2 between them. The emissions from other activities, e.g. industrial and traffic, are assumed to be seasonally independent.

\section{Summary}

In this study we have estimated the emissions of primary pollutants $\mathrm{SO}_{2}, \mathrm{NO}_{\mathrm{x}}, \mathrm{VOC}, \mathrm{CO}, \mathrm{NH}_{3}, \mathrm{PM}_{10}, \mathrm{PM}_{2.5}$, EC, and $\mathrm{OC}$ in the Huabei region of China in 2003. In an administrative sense, Huabei includes the Beijing and Tianjin Municipalities, the Hebei and Shanxi Provinces, and the Inner-Mongolia Autonomous Region. The estimated total emissions in the Huabei administrative region in 2003 are $4.73 \mathrm{Tg} \mathrm{SO}, 2.72 \mathrm{Tg} \mathrm{NO}$ (in equivalent $\mathrm{NO}_{2}$ ), $1.77 \mathrm{Tg}$ VOC, 24.14 Tg CO, $2.03 \mathrm{Tg} \mathrm{NH}, 4.57 \mathrm{Tg} \mathrm{PM}_{10}, 2.42 \mathrm{Tg}$ $\mathrm{PM}_{2.5}, 0.21 \mathrm{Tg} \mathrm{EC}$, and 0.46 Tg OC. For model convenience, we consider a larger Huabei region with Shandong, Henan and Liaoning Provinces included in our inventory. The estimated total emissions in the larger Huabei region in 2003 are $9.55 \mathrm{Tg} \mathrm{\textrm {SO } _ { 2 }}, 5.27 \mathrm{Tg} \mathrm{NO}_{\mathrm{x}}$ (in equivalent $\mathrm{NO}_{2}$ ), $3.82 \mathrm{Tg}$ 
VOC, 46.59 Tg CO, 5.36 Tg $\mathrm{NH}_{3}, 10.74 \mathrm{Tg} \mathrm{PM}_{10}, 5.62 \mathrm{Tg}$ $\mathrm{PM}_{2.5}, 0.41 \mathrm{Tg} \mathrm{EC}$, and $0.99 \mathrm{Tg} \mathrm{OC}$.

The estimated emission rates have been projected into fine-grid cells at a horizontal resolution of $0.1^{\circ}$ latitude by $0.1^{\circ}$ longitude. Our gridded emission inventory includes the area sources from industrial, civil, traffic, and straw burning activities plus 345 large industrial point sources from power plants, iron and steel plants, cement plants, and chemical plants. Except for a factor of 3 lower EC emission rate in comparison with INTEX-B, the biases of the total emissions of most primary air pollutants in Huabei estimated in our inventory, with respect to EDGAR-CIRCE and INTEX-B, generally range from $-30 \%$ to $+40 \%$. Large differences up to a factor of 2-3 for local emissions in some areas (e.g. Beijing and Tianjin) are found. Our inventory will be likely to provide more practical spatial distributions of pollutant emissions for the year 2003 in comparison with existing global or Asian emission inventories.

\section{Supplementary material related to this article is available online at: http://www.atmos-chem-phys.net/12/481/2012/ acp-12-481-2012-supplement.zip.}

Acknowledgements. This work was funded by the CMA project GYHY(QX)-200706005 and the NSFC projects 40433008, 40775073 and 41075095 . We would like to thank Jos Lelieveld, Mark Lawrence and Tim Butler of MPIC for their help on this work. We also thank the two anonymous reviewers for their constructive comments on the manuscript.

Edited by: T. Wang

\section{References}

Andreae, M. O. and Merlet, P.: Emission of trace gases and aerosols from biomass burning, Global Biogeochem. Cy., 15, 955-966, doi:10.1029/2000gb001382, 2001.

Bai, N. B.: The emission inventory of $\mathrm{CO}_{2}, \mathrm{SO}_{2}$, and $\mathrm{NO}_{\mathrm{x}}$ in China, in: The Atmospheric Ozone Variation and Its Effect on the Climate and Environment in China, edited by: Zhou, X. J., Meteorological Press, Beijing, 1996.

Bo, Y., Cai, H., and Xie, S. D.: Spatial and temporal variation of historical anthropogenic NMVOCs emission inventories in China, Atmos. Chem. Phys., 8, 7297-7316, doi:10.5194/acp-8-72972008, 2008.

Bobley, D., Deslauriers, M., and Rojas-Brachos, L.: Improving emission inventroies for effective air quality management across North America: a NARSTO assessment, NARSTO Assembly Meeting, Las Vegas, NV, 2005.

Bond, T. C., Streets, D. G., Yarber, K. F., Nelson, S. M., Woo, J.H., and Klimont, Z.: A technology-based global inventory of black and organic carbon emissions from combustion, J. Geophys. Res., 109, D14203, doi:10.1029/2003jd003697, 2004.

Butler, T. M., Lawrence, M. G., Gurjar, B. R., van Aardenne, J., Schultz, M., and Lelieveld, J.: The representation of emissions from megacities in global emission inventories, Atmos. Environ., 42, 703-719, 2008.

Cai, H. and Xie, S. D.: Estimation of vehicular emission inventories in China from 1980 to 2005, Atmos. Environ., 41, 8963-8979, doi:10.1016/j.atmosenv.2007.08.019, 2007.

Cai, H. and Xie, S. D.: Tempo-spatial variation of emission inventories of speciated volatile organic compounds from onroad vehicles in China, Atmos. Chem. Phys., 9, 6983-7002, doi:10.5194/acp-9-6983-2009, 2009.

Cao, G. L.: Inventory of black carbon and organic carbon emissions for mainland China, $\mathrm{PhD}$, Institute of Earth Environment, Chinese Academy of Sciences, Xi'an, 112 pp., 2005.

Cao, G. L., Zhang, X. Y., Wang, Y. Q., and Zheng, F. C.: Estimation of emissions from field burning of crop straw in China, Chin. Sci. Bull., 53, 784-790, doi:10.1007/s11434-008-0145-4, 2008.

Carmichael, G. R., Tang, Y., Kurata, G., Uno, I., Streets, D. G., Thongboonchoo, N., Woo, J. H., Guttikunda, S., White, A., Wang, T., Blake, D. R., Atlas, E., Fried, A., Potter, B., Avery, M. A., Sachse, G. W., Sandholm, S. T., Kondo, Y., Talbot, R. W., Bandy, A., Thorton, D., and Clarke, A. D.: Evaluating regional emission estimates using the TRACE-P observations, J. Geophys. Res., 108, 8810, doi:10.1029/2002jd003116, 2003.

China Ministry of Agriculture/U.S. Department of Energy Project Panel. Assessment of China Biomass Resource Availability, China Environmental Sciences Press, Beijing, 1998.

China Statistic Bureau: Province and City Statistical Yerabook 2004, China Statistical Publisher, Beijing, 2004a.

China Traffic Yearbook Editorial Board: China Traffic Yerabook 2004, China Traffic Publisher, Beijing, 2004b.

China Steel Indsutrial Association: China Steel Yerabook 2004, China Statistical Publisher, Beijing, 2004c.

China Electric Power Yearbook Editorial Board: China Electric Power Yerabook 2004, China Electric Power Publisher, Beijing, 2004d.

China Statistic Bureau: China Engery Statistical Yerabook 2004, China Statistical Publisher, Beijing, 2004e.

Cooke, W. F., Liousse, C., Cachier, H., and Feichter, J.: Construction of a $1^{\circ} \times 1^{\circ}$ fossil fuel emission data set for carbonaceous aerosol and implementation and radiative impact in the ECHAM4 model, J. Geophys. Res., 104, 22137-22162, doi:10.1029/1999jd900187, 1999.

Crutzen, P. J. and Andreae, M. O.: Biomass burning in the tropics:impact on atmospheric chemistry and biogeochemical cycles, Science, 28, 213-225, 1990.

Dai, T. Y., Wang, W., Ren, L. H., Chen, J. H., and Liu, H. J.: Emissions of non-methane hydrocarbons from cars in China, Sci. China-Chem., 53, 263-272, doi:10.1007/s11426-010-00026, 2010.

Dentener, F., Stevenson, D., Cofala, J., Mechler, R., Amann, M., Bergamaschi, P., Raes, F., and Derwent, R.: The impact of air pollutant and methane emission controls on tropospheric ozone and radiative forcing: CTM calculations for the period 19902030, Atmos. Chem. Phys., 5, 1731-1755, doi:10.5194/acp-51731-2005, 2005.

Doering, U., Monni, S., Pagliari, V., Orlandini, L., van Aardenne, J., and SanMartin, F.: CIRCE report D8.1.1 Emission inventory for the past period 1990-2005 on 0.1x0.1 grid, Tech. rep., Project FP6: 6.3, No. 036961, 2009a.

Doering, U., van Aardenne, J., Monni, S., Pagliari, V., Orlandini, L., 
and SanMartin, F.: CIRCE report D8.1.2 - Evaluation emission database 1990-2005, Tech. rep., Project FP6: 6.3, No. 036961, 2009b.

Fine, P. M., Cass, G. R., and Simoneit, B. R. T.: Chemical characterization of fine particle emissions from fireplace combustion of woods gown in the northeastern US, Environ. Sci. Technol., 35, 2665-2675, 2001.

Frey, H. C., Bharvirkar, R., and Zheng, J.: Quantitative analysis of variability and uncertainty in emissions estimation. Prepared by North Carolina State University for the U.S. Environmental Protection Agency, Research Triangle Park, NC, 1999.

He, D., Hao, J., He, K., and Fu, L.: Vehicle emission factors determination using model calculation, Chinese Journal of Enviromental Science, 19, 7-10, 1998.

Jacob, D. J., Crawford, J. H., Kleb, M. M., Connors, V. S., Bendura, R. J., Raper, J. L., Sachse, G. W., Gille, J. C., Emmons, L., and Heald, C. L.: Transport and Chemical Evolution over the Pacific (TRACE-P) aircraft mission: Design, execution, and first results, J. Geophys. Res., 108, 9000, doi:10.1029/2002jd003276, 2003.

Jenkins, B. M., Turn, S. Q., Williams, R. B., Goronea, M., Abd-elFattah, H., Mehlschau, J., Raubach, N., Chang, D. P. Y., Kang, M., and Teague, S. V.: Atmospheric pollutant emission factors from open burning of agricultural and forest biomass by wind tunnel simulations, California State Air Resources Board, Sacramento, CA, 1996.

Jiang, X. and Tang, X.: Reaserch on Air Pollution Control Strategy for the Beijing City, Beijing Environmental Protection Bureau \& Peking University, Beijing, 268 pp., 2002.

Lei, Y., Zhang, Q., He, K. B., and Streets, D. G.: Primary anthropogenic aerosol emission trends for China, 1990-2005, Atmos. Chem. Phys., 11, 931-954, doi:10.5194/acp-11-931-2011, 2011.

Li, W., Fu, L. X., Hao, J. M., Ma, H., Li, S., and Hu, W.: Emission inventory of 10 kinds of air pollutants for road traffic vehicles in China, Urban Environment \& Urban Ecology, 16, 36-38, 2003.

Liu, H., He, K., and Barth, M.: Traffic and emission simulation in China based on statistical methodology, Atmos. Environ., 45, 1154-1161, 2011.

Liu, Y. and Shao, M.: Estimation and prediction of black carbon emissions in Beijing City, Chin. Sci. Bull., 52, 1274-1281, doi:10.1007/s11434-007-0162-8, 2007.

Lu, Z., Streets, D. G., Zhang, Q., Wang, S., Carmichael, G. R., Cheng, Y. F., Wei, C., Chin, M., Diehl, T., and Tan, Q.: Sulfur dioxide emissions in China and sulfur trends in East Asia since 2000, Atmos. Chem. Phys., 10, 6311-6331, doi:10.5194/acp-106311-2010, 2010.

Ma, J. and van Aardenne, J. A.: Impact of different emission inventories on simulated tropospheric ozone over China: a regional chemical transport model evaluation, Atmos. Chem. Phys., 4, 877-887, doi:10.5194/acp-4-877-2004, 2004.

Ma, J., Richter, A., Burrows, J. P., Nüß, H., and van Aardenne, J. A.: Comparison of model-simulated tropospheric $\mathrm{NO}_{2}$ over China with GOME-satellite data, Atmos. Environ., 40, 593-604, 2006.

Ma, J., Chen, Y., Wang, W., Yan, P., Liu, H., Yang, S., Hu, Z., and Lelieveld, J.: Strong air pollution causes widespread haze-clouds over China, J. Geophys. Res., 115, D18204, doi:10.1029/2009jd013065, 2010.

Ma, J. Z., Wang, W., Chen, Y., Liu, H. J., Yan, P., Ding, G. A., Wang, M. L., and Lelieveld, J.: The IPAC-NC field campaign: a pollution and oxidization pool in the lower atmosphere over Huabei, China, Atmos. Chem. Phys. Discuss., 11, 27701-27762, doi:10.5194/acpd-11-27701-2011, 2011.

Ohara, T., Akimoto, H., Kurokawa, J., Horii, N., Yamaji, K., Yan, X., and Hayasaka, T.: An Asian emission inventory of anthropogenic emission sources for the period 19802020, Atmos. Chem. Phys., 7, 4419-4444, doi:10.5194/acp-7-4419-2007, 2007.

Olivier, J. G. J., Peters, J. A. H. W., Bakker, J., Berdowski, J. J. M., Visschedijk, A. J. H., and Bloos, J. P. J.: Applications of EDGAR: emission database for global atmospheric research, RIVM, The Netherlands, Report. no. 410.200.051, 2002.

Olivier, J. G. J., van Aardenne, J. A., Dentener, F. J., Pagliari, V., Ganzeveld, L. N., and Peters, J. A. H. W.: Recent trends in global greenhouse gas emissions:regional trends 1970-2000 and spatial distributionof key sources in 2000, Journal of Integrative Environmental Sciences, 2, 81-99, 2005.

Pang, X. B. and Mu, Y. J.: Characteristics of carbonyl compounds in public vehicles of Beijing city: Concentrations, sources, and personal exposures, Atmos. Environ., 41, 18191824, doi:10.1016/j.atmosenv.2006.10.057, 2007.

Pozzer, A., de Meij, A., Pringle, K. J., Tost, H., Doering, U. M., van Aardenne, J., and Lelieveld, J.: Aerosol simulation applying high resolution anthropogenic emissions with the EMAC chemistryclimate model, Atmos. Chem. Phys. Discuss., 11, 25205-25261, doi:10.5194/acpd-11-25205-2011, 2011.

Pulles, T., van het Bolscher, M., Brand, R., and Visschedijk, A.: Assessment of global emissions from fuel combustion in the final decades of the 20th century. Application of the emission inventory model TEAM, Technical Report A-R0132B, Netherlands Organisation for Applied Research (TNO), Apeldoorn, The Netherlands, 2007.

Reddy, M. S. and Venkataraman, C.: Inventory of aerosol and sulphur dioxide emissions from India: I - Fossil fuel combustion, Atmos. Environ., 36, 677-697, 2002.

Richter, A., Burrows, J. P., Nusz, H., Granier, C., and Niemeier, U.: Increase in tropospheric nitrogen dioxide over China observed from space, Nature, 437, 129-132, 2005.

Russell, A. and Dennis, R.: NARSTO critical review of photochemical models and modeling, Atmos. Environ., 34, 2283-2324, 2000.

Seiler, W. and Crutzen, P., J.: Estimates of gross and net fluxes of carbon between the biosphere and atmosphere from biomass burning, Climatic Change, 2, 207-247, 1980.

SEPA: Emission standard of air pollutants for thermal power plants, State Environmental Protection Administartion of China, GB13223-2003, 2003.

Singh, H. B., Brune, W. H., Crawford, J. H., Flocke, F., and Jacob, D. J.: Chemistry and transport of pollution over the Gulf of Mexico and the Pacific: spring 2006 INTEX-B campaign overview and first results, Atmos. Chem. Phys., 9, 2301-2318, doi:10.5194/acp-9-2301-2009, 2009.

Streets, D. G., Gupta, S., Waldhoff, S. T., Wang, M. Q., Bond, T. C., and Yiyun, B.: Black carbon emissions in China, Atmos. Environ., 35, 4281-4296, 2001.

Streets, D. G., Bond, T. C., Carmichael, G. R., Fernandes, S. D., Fu, Q., He, D., Klimont, Z., Nelson, S. M., Tsai, N. Y., Wang, M. Q., Woo, J. H., and Yarber, K. F.: An inventory of gaseous and primary aerosol emissions in Asia in the year 2000, J. Geophys. 
Res., 108, 8809, doi:10.1029/2002jd003093, 2003.

Sun, Q. and Wang, M.: Ammonia emission and concentration in the atmosphere over China, Scientia Atmospherica Sinica, 21, 590-598, 1997.

Tang, D. G., Zhang, Y. H., and Li, J. L.: Automobile Pollution Control System and Implementation Mechanism, Chinese Research Academy of Environmental Sciences, Pekin University, and Guangzhou Institute of Environmental Sciences, Report 96910-03-01, 1-61, 1999.

Tian, H., Hao, J., Lu, Y., and Zhu, T.: Inventories and distribution characteristics of NOX emissions in China, CHina Environmental Science, 21, 493-497, 2001.

Tian, H., Hao, J., Lu, Y., and Zhou, Z.: Evaluation of $\mathrm{SO}_{2}$ and $\mathrm{NO}_{\mathrm{x}}$ emissions resulted from biomass fuels utilization in China, Acta Scientiae Circumstantiae, 22, 204-208, 2002.

UNEP: The Fertilizer Industry's Manufacturing Processes and Environmental Issues, Mineral Fertilizer Production and the Environment, Part 1, France:IFA, 73 pp., 1996.

U.S. EPA: Emissions Factors \& AP 42, 2006a.

UK NAEI: The Methodology of the National Atmospheric Emissions Inventory, Appendix 1(2.3), $2006 \mathrm{~b}$.

Van Aardenne, J. A.: Uncertainties in emission inventories. Doctor's Degree Thesis, Wageningen University, The Netherlands, 2002.

Wang, L., Zhang, Q., Hao, J., and He, K.: Anthropogenic CO emission inventory of Mainland China, Acta Scientiae Circumstantiae, 25, 1580-1585, 2005a.

Wang, L. Z., Sui, Q., XIie, Q., and Yu, Y. Q.: Definition of emission factor of vehicle in Jinan, Environmental Protection In Transportation, 23, 18-20, 2002.

Wang, X., Mauzerall, D. L., Hu, Y., Russell, A. G., Larson, E. D., Woo, J.-H., Streets, D. G., and Guenther, A.: A high-resolution emission inventory for eastern China in 2000 and three scenarios for 2020, Atmos. Environ., 39, 5917-5933, 2005b.

Wang, Y.: The studies on the characteristic of motor vehicle particle emissions in Beijing district, $\mathrm{PhD}$, Jilin University, Changchun, 108 pp., 2002.

Yang, Y. X., Cai, X. L., Du, Q., Liu, C. W., Liu, J., and Jiin, Z. G.: Research on the real road emission factors and fuel consumption of typical vehicles on the roads, Journal of Combustion Science and Technology, 9, 112-118, 2003.
Zhang, Q., Klimont, Z., Streets, D. G., Huo, H., and He, K.: An anthropogenic PM emission model for China and emission inventory for the year 2001, Prog. Nat. Sci., 16, 223-231, 2006.

Zhang, Q., Streets, D. G., Carmichael, G. R., He, K. B., Huo, H., Kannari, A., Klimont, Z., Park, I. S., Reddy, S., Fu, J. S., Chen, D., Duan, L., Lei, Y., Wang, L. T., and Yao, Z. L.: Asian emissions in 2006 for the NASA INTEX-B mission, Atmos. Chem. Phys., 9, 5131-5153, doi:10.5194/acp-9-5131-2009, 2009.

Zhao, B. and Ma, J. Z.: Development of air pollutant emission inventory for Tianjin, Acta Scientiae Circumstiae, 28, 368-375, 2008.

Zhao, Y., Wang, S. X., Duan, L., Lei, Y., Cao, P. F., and Hao, J. M.: Primary air pollutant emissions of coal-fired power plants in China: Current status and future prediction, Atmos. Environ., 42, 8442-8452, doi:10.1016/j.atmosenv.2008.08.021, 2008.

Zhao, Y., Nielsen, C. P., Lei, Y., McElroy, M. B., and Hao, J.: Quantifying the uncertainties of a bottom-up emission inventory of anthropogenic atmospheric pollutants in China, Atmos. Chem. Phys., 11, 2295-2308, doi:10.5194/acp-11-2295-2011, 2011.

Zheng, J. Y.: Quantification of variability and uncertainty in emission estimation: General methodology and software Implementation, Ph.D. dissertation, Department of Civil Engineering, North Carolina State University, Raleigh, NC, 2002.

Zheng, J. Y., Shao, M., Che, W. W., Zhang, L. J., Zhong, L. J., Zhang, Y. H., and Streets, D.: Speciated VOC Emission Inventory and Spatial Patterns of Ozone Formation Potential in the Pearl River Delta, China, Environ. Sci. Technol., 43, 8580-8586, doi:10.1021/es901688e, 2009a.

Zheng, J. Y., Zhang, L. J., Che, W. W., Zheng, Z. Y., and Yin, S. S.: A highly resolved temporal and spatial air pollutant emission inventory for the Pearl River Delta region, China and its uncertainty assessment, Atmos. Environ., 43, 5112-5122, doi:10.1016/j.atmosenv.2009.04.060, 2009b.

Zhu, B., Zhu, X. L., X., Z. Y., Zeng, L. M., and Zhang, Y. H.: Emission factor of $\mathrm{PM}_{2.5}$ from crop straw burning, Research of Environmental Sciences, 18, 29-33, 2005.

Zhu, S. L.: Study on emission factors of GHG and pollutants from rural stoves in developing countries, Renewable Energy, 114, 1619, 2004. 